\title{
TRACE ELEMENTS AND ANORTHOSITE GENESIS
}

\author{
JEAN-CLAIR DUCHESNE \\ Géologie, Pétrologie et Géochimie, Université de Liège, Sart Tilman (Belgium)
}

\author{
DANIEL DEMAIFFE \\ Laboratoire de Minéralogie et Pétrologie, Université Libre de Bruxelles, Bruxelles (Belgium), also Musée Royal \\ de l'Afrique Centrale, Tervuren, Belgium.
}

\begin{abstract}
Terrestrial massif anorthosites have gained new interest for the understanding of the deep zones of the crust and for the reconstitution of its history in Proterozoic time. The purpose of this paper is to show how trace elements can enlighten two controversial questions in the problem of anorthosites, namely the nature of the parental magma and the process which gives rise to related acidic rocks. Data obtained on rocks and minerals coming from the Rogaland anorthositic province, South Norway, are presented together with those available in the literature. The $\mathrm{Sr}$ and $\mathrm{Ba}$ in plagioclase and their relationship with $\mathrm{Ca}$ and $\mathrm{K}, \mathrm{K}$ and $\mathrm{Rb}$ in rocks and plagioclases, rare earth elements (REE) in cumulate minerals and in various liquids, ${ }^{87} \mathrm{Sr} /{ }^{86} \mathrm{Sr}$ initial ratios on rocks and minerals as well as a few data on transition elements and on ${ }^{18} \mathrm{O} /{ }^{16} \mathrm{O}$ ratios are discussed in the different sections. Quantitative modelling of the behaviour of trace elements is realized mainly by graphical methods in the Bjerkrem-Sogndal layered lopolith and in the Hidra body, both andesine-type massifs. The major conclusions are as follows:
\end{abstract}

(1) The parental magma of the andesine-type massifs has a jotunitic (hypersthene-monzodioritic) composition characterized by variable $\mathrm{K} / \mathrm{Rb}$ ratios (from 480 to 1700), by the absence of an Eu anomaly, by variable REE contents (from 50 to 220 for La chondrite-normalized content) and by La/Yb ratios almost constant (from 6 to 12), as well as by high Ti and Fe contents, by transition elements indicating calc-alkaline affinities and by ${ }^{87} \mathrm{Sr} /{ }^{86} \mathrm{Sr}$ initial ratios similar to those of rocks derived from the upper mantle or the deep crust.

(2) A jotunitic composition appears not to be compatible with the parental magma of the labradorite-type massif anorthosite. The relationship between andesine anorthosite and labradorite anorthosite cannot be described simply in terms of fractional crystallization.

(3) Fractional crystallization can explain the succession of rocks from andesine anorthosite to leuconorite, to norite and finally to acidic rocks. In some cases however, namely the Bjerkrem-Sogndal lopolith in Rogaland, contamination by supracrustal material must be invoked and seems to have superimposed its effects on those of fractional crystallization.

(4) Deformation, granulation and recrystallization do not appear to fractionate both the major and trace elements of the plagioclase, except Ti which is lowered.

\section{Introduction}

Terrestrial massif anorthosites may be considered the most important basic plutonic phenomenon in the deep zone of the earth's crust [1]. They represent in some provinces (e.g. Grenville) more than $25 \%$ of the crystalline terrains and can form plutons of batholitic dimensions. They occur most frequently in high-grade metamorphic terrains of granulite facies or transitional between amphibolite and granulite facies. Their emplacement can be syn- or post-tectonic; many massifs have, however, been affected by subsequent deformation and recrystallization (meta-anorthosites).

Anorthosites are absent from Phanerozoic terrains; they occur dominantly in Mid-Proterozoic (1800 - 1000 m.y.) and in Archaean terrains (>2500 m.y.) and seem to constitute, in paleogeodynamic reconstructions before drifting of the continents, either two broad belts (one in Laurasia and the other in Gondwana) [2] or a unique great circle belt in a super-continent [3]. They are usually associated with mafic rocks of gabbroic or noritic types which may also include troctolites, with intermediate jotunitic rocks (hypersthene monzodiorite, monzonorite) and with acidic rocks (hypersthene monzonite, mangerite, quartz mangerite, charnockite, etc.). All these rocks belong to the charnockite category and may be referred to as the anorthositic suite.

Two great types of massif anorthosites can be distinguished on the basis of the nature of the plagio-clase: the andesine and the labradorite anorthosites. Recent review papers [4,5] summarize and discuss the main geological 
characteristics of these rocks.

In addition to their intrinsic interest and the numerous problems raised by their genesis, anorthosites have drawn the attention of scientists in various fields of geology. Their frequent association with granulites suggests that they largely occur in the deep continental crust between the Conrad and Moho discontinuities [6-8]. Their occurrence is restricted to two ancient periods (Archaean and Mid-Proterozoic). This questions the uniformitarism principle and has several implications on the formation and evolution of the ancient continental crust. Russian geologists (see Pavlovsky [9]) consider the Siberian anorthosites as relics of a primeval gabbroanorthositic crust. Their arrangement in one or two belts of planetary extension is one of the (rare) constraints available to establish convection models in Proterozoic times [3] or initiation of chemical plumes [10]. The high density of occurrence of massif anorthosites in some provinces leads Martignole and Schrijver [11] to envisage the intrusion mechanism as being the cause — rather than the result — of deep-seated regional deformations. Dewey and Burke [12] believe that massif anorthosites are generated through reactivation or re-cycling of continental crust.

It thus appears that any contribution to the "problem of anorthosites" is likely also to improve our knowledge about Proterozoic palaeogeodynamics as well as the geology of the deep zones of the earth's crust. Moreover, as anorthositic rocks constitute a large part of the lunar highlands $[13,14]$, further data on terrestrial anorthosites will also clarify the geological evolution of the moon.

In the present state of knowledge on terrestrial anorthosites, one of the major difficulties hampering the geologists is the nature of the parental magma of the anorthositic suite. Chilled margins are exceptional and their composition is very variable. Geologists have therefore tried to estimate the composition of the magma by adding the volumes of rocks which would derive from it. Besides the inaccuracies due to the method itself, a further difficulty arises from the fact, not universally admitted, that acidic rocks associated with anorthosites belong to the same magmatic series. Several authors following Buddington $[15,16]$ admit that acidic rocks are cogenetic with anorthosites but question their comagmatism. They could derive from a different magma produced for instance by anatexis. Other authors follow Bo wen [17] and include the acidic rocks as belonging to the series (e.g. [6,18-20]). Yet, others, following Kranck [21], also include Rapakivi granites into the series on the basis of chemical similarities. These granites could be residual liquids left by the crystallization of massif anorthosites and emplaced in upper levels of the crust.

It is thus not surprising that there is little agreement among geologists and petrologists on the nature of the parental magma: a wide range of compositions from basalt to granodiorite are put forth.

In this controversial problem we think that trace element geochemistry is likely to enlighten the question from a different angle and bring it nearer its solution. We have chosen to concentrate on anorthosites and related rocks coming from Rogaland (South Norway). This petrographic province has been studied from the geological and petrological points of view by Paul Michot and Jean Michot (Jr.) and their associates. Its geological evolution and the main features of the petrogenesis of the different units are known to an extent seldom achieved in other provinces. The andesine-type massif anorthosites predominate in the province, but labradorite anorthosites and meta-anorthosites are also known, as well as a layered anorthositic-mangeritic lopolith and synkinematic and postkinematic bodies. In short, this key region for the problem of anorthosites permits to study the various rock types in all the different geological settings also found elsewhere. We shall not, however, deal with the Archaean anorthosites which appear to constitute a separate category, and for which very few trace element data are available $^{*}$; they are not of the massif type and contain very anorthite-rich plagioclase and chromite. They would seem to represent fragments of old layered bodies of basaltic origin deformed in catazonal environment together with their metamorphic envelope [23].

The main features of the geological model of Paul Michot have been published elsewhere [24,25] (Fig. 1). Complementary data have been added subsequently [4,26]. Only features essential to the understanding of the geochemical point of view will be recalled here.

The Egersund-Ogna body, the oldest in the province, is of the massif type. It is made of an anorthosite whose

\footnotetext{
* Preliminary REE determinations on the Fiskenaesset complex, West Greenland [22], indicate very low contents and higher La/Yb ratios in plagioclase compared to many other anorthositic complexes.
} 
plagioclase $\left(\mathrm{An}_{40}\right.$ to $\left.\mathrm{An}_{45}\right)$ has a grain size of the order of $1 \mathrm{~cm}$. Locally plagioclase megacrysts $(>10 \mathrm{~cm}) \mathrm{can}$ be found as well as, more rarely, "giant" orthopyroxene $(>50 \mathrm{~cm})$ with plagioclase exsolutions [27]. The inner border of the body is made of strongly foliated leuconorite (meta-leuconorite); the plagioclase is a labradorite $\left(\mathrm{An}_{50}\right.$ to $\left.\mathrm{An}_{70}\right)$ and olivine $\left(\mathrm{Fo}_{70}\right)$ can coexist with orthopyroxene. Clinopyroxene, apatite and oxides are absent. Gneissic structures are not restricted to the border but can reach in some places central parts of the body. The thin Lakssvelefjeld-Koldal noritic intrusion, migmatitic in place, girdles the massif.

Fig. 1. General geological map of the Rogaland igneous complex and southeastern satellites (after Michot and Michot [25]).

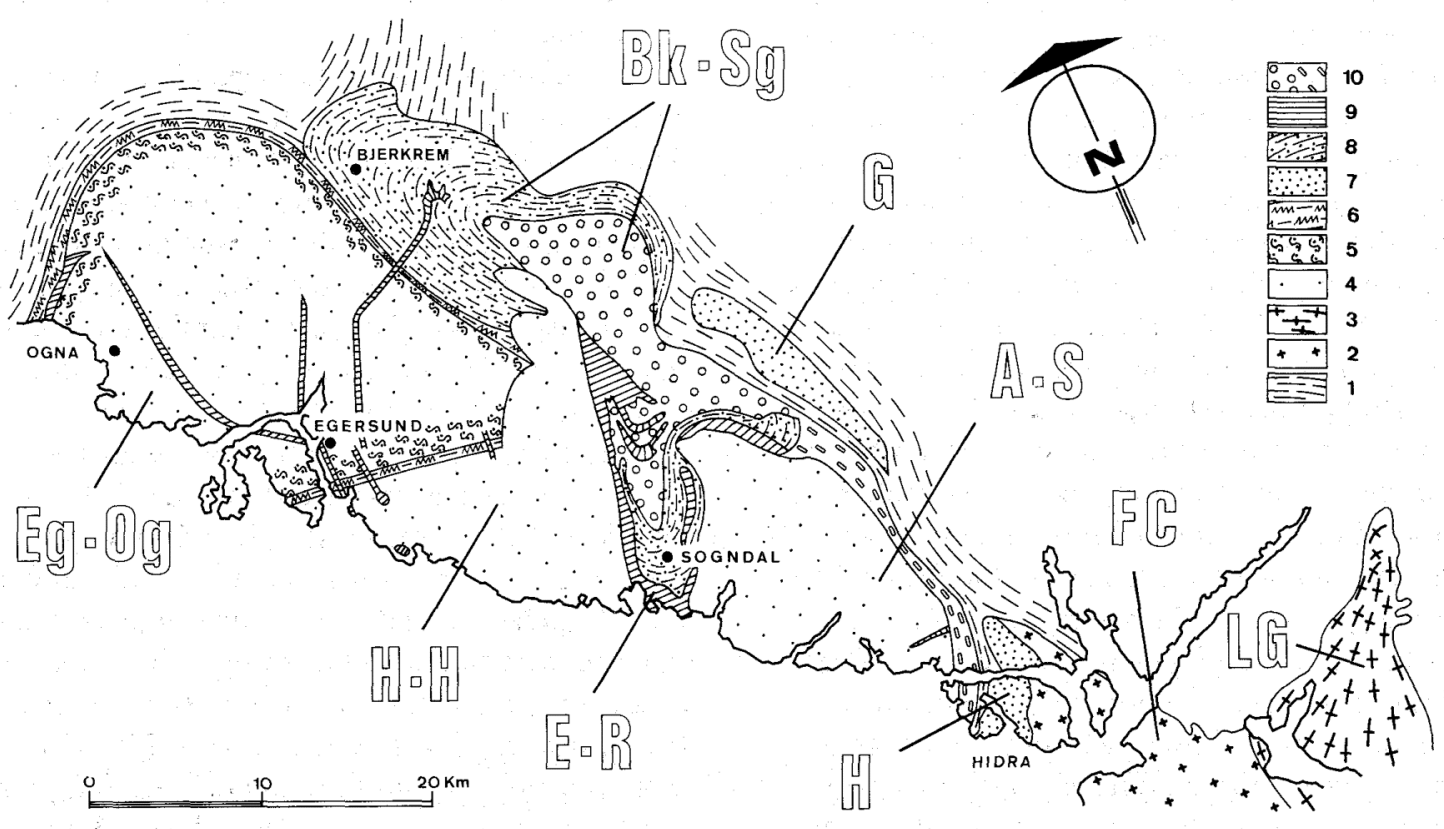

Eg-Og = Egersund-Ogna body; H-H = Håland-Helleren massif; A-S = Åna-Sira body ; Bk-Sg = Bjerkrem-Sogndal lopolith; E-R = EiaRekefjord intrusion; $\mathrm{FC}=$ Farsund charnockite; $\mathrm{LG}=$ Lyngdal hornblende-granodiorite; $\mathrm{G}=\mathrm{Garsaknatt}$ body; $\mathrm{H}=\mathrm{Hidra}$ body .

Legend. 10 = circle: mangerite and quartz mangerite; oval: noritic-mangeritic complex; $9=$ quartz jotunite of the Eia-Rekefjord intrusion; $8=$ layered an orthosite, leuconorite, norite and jotunite of the Bjerkrem-Sogndal lopolith; $7=$ leuconorite arid anorthosite; $6=$ norite, locally migmatitic, of the Lakssvelefjeld-Koldal intrusion; 5 = leuconoritic gneiss; 4 = anorthosite; 3 = Lyngdal hornblende-granodiorite; $2=$ Farsund charnockite; 1 = surrounding gneisses.

The Bjerkrem-Sogndal body is a synkinematic layered lopolith [24,28] which displays the complete series of rocks from anorthosite to quartz mangerite (hypersthene, mesoperthite-granite). It results from gravity differentiation. Rocks are characterized by macro- and micro-textures typical of igneous layered cumulates (lamination, small-scale rhythmic layering, banding, etc.). Taking into account recurrences due to successive influxes of fresh magma, the evolution of the mineralogy throughout the whole sequence of rocks [28-30] is as follows: in the anorthosites, the leuconorites and the lower part of the norites, an unzoned plagioclase $\left(\mathrm{An}_{50}\right.$ to $\left.\mathrm{An}_{43}\right)$ is associated with an orthopyroxene and oxides; in the norites upwards in the sequence, clinopyroxene and apatite appear as additional cumulate minerals and plagioclase is more albitic $\left(\mathrm{An}_{45}\right.$ to $\left.\mathrm{An}_{40}\right)$. Still higher in the norites, potassium feldspar appears - first as antiperthite, then progressively as a cumulate mineral - and the rocks grade into jotunitic (hypersthene monzodioritic) cumulates which constitute a rapid transition towards the mangeritic phase: mangerites (hypersthene, mesoperthite-monzonite) and, on top of the massif, quartz mangerites. Intimately associated with the southern part of the lopolith is the quartz jotunitic intrusion of EiaRekefjord [24], which was emplaced in a stage a brittle deformation of the lopolith. An extensive network of dykes is related to this unit.

The Håland-Helleren [31] and Ana-Sira bodies are made of a complex association between anorthosites and norites with all transitions between these two rock types. Phenocrysts are commonly found in matrix of anorthositic to noritic composition. Banded anorthositic-leuconoritic gneisses, locally folded, constitute large parts of the bodies — namely in the surroundings of Håland — or are found as inclusions in the anorthositic- 
noritic rocks. According to J. Michot [32] it is not possible to distinguish whether these bodies result from fractional crystallization or from anatexis.

The anorthositic-leuconoritic bodies of Hidra [26,33] and Garsaknatt are intrusive in the surrounding gneisses. They clearly appear as post-tectonic and are thus the latest anorthositic intrusions in the province. They are characterized by occurrence of a chilled margin of jotunitic nature, locally porphyritic (phenocrysts from 1 to 5 $\mathrm{cm}$ ), which passes gradually to the leuconorite forming the central part of the body. In Hidra a network of charnockitic dykes and acidic pegmatites develops after the solidification of the massif.

The southeast end of the magmatic province is occupied by two distinct bodies of acidic rocks: the Farsund charnockite and the Lyngdal hornblende-granodiorite. The two massifs, long considered as a single intrusion (the so-called Farsundite), are clearly distinguishable on the basis of the mineralogy and geochemistry [34]. The genetic relationships between these two acidic rocks and with the neighbouring anorthosites are not very clear.

Available geochemical data ${ }^{*}$ on the different units of the province are classified into sections dealing with $\mathrm{Sr}$ and $\mathrm{Ba}$ in plagioclases, $\mathrm{K}$ and $\mathrm{Rb}$ in plagioclases and rocks, rare earth elements (REE) in Bjerkrem-Sogndal cumulates and various liquids, transition elements and $\mathrm{Sr}$ and $\mathrm{O}$ isotopes. In each case data from the literature are integrated with those from Rogaland. The interpretation which follows is mostly based on quantitative modelling. This presentation will make clear the methodological interest of each group of elements in solving some peculiar aspects of the problem of anorthosites. It is hoped that this approach will stimulate further trace element studies on anorthosites.

\section{Strontium and barium in plagioclase}

Strontium and $\mathrm{Ba}$ are trace elements interesting to study in plagioclase in relationship with the $\mathrm{Ca}$ and $\mathrm{K}$ contents of the mineral.

Available data are schematically plotted in Figs 2 and 3. They concerned the Nain massif [35] and the Labrieville massif [36], as well as anorthositic inclusions in North Minnesota, U.S.A., and Iceland dolerites [37]. Data from South Norway are the most abundant ([37-40] ; R. Zeino-Mahmalat, personal communication, 1975).

The $\mathrm{Sr}$ and $\mathrm{Ba}$ contents present variations from 300 to $1800 \mathrm{ppm}$ for $\mathrm{Sr}$ and from 10 to $1000 \mathrm{ppm}$ for Ba. The overall trends show an enrichment in $\mathrm{Sr}$ with a decrease in $\mathrm{Ca}$ and simultaneous increase of Ba with $\mathrm{K}$. A negative correlation between $\mathrm{K}$ and $\mathrm{Ca}$ is also recognized when Figs 2 and 3 are combined.

If trends peculiar to each body are considered (Fig. 2), it is observed that the data present more restricted ranges and more diversified trends than in the overall trends. For instance, the Sr-Ca relationship in Bjerkrem-Sogndal plagioclases is characterized by a zig-zag pattern; the Egersund-Ogna body presents wide variations in $\mathrm{Sr}-\mathrm{Ca}$ and $\mathrm{Ba}-\mathrm{K}$, which are approximatly parallel to those defined for the Nain.

Such evidence can be used to refine the classification of anorthosites. It can also help in solving field relations (e.g. determining the provenance of xenoliths [41]). Its major interest, however, lies in that it constitutes precise constraints that must be satisfied by the petrogenetic models. The following examples illustrate the use of the $\mathrm{Sr}$ $\mathrm{Ca}$ and $\mathrm{Ba}-\mathrm{K}$ relationships.

\subsection{Megacrysts and partition coefficients}

Large-size plagioclase phenocrysts $(10-100 \mathrm{~cm})$ which occur in the Hidra, Helleren, Ana-Sira and the central part of the Egersund-Ogna massifs show compositions very similar to each other (Table 1). Values reported by R. Zeino-Mahmalat (personal communication, 1975) on Åna-Sira phenocrysts are very little scattered and not significantly different from our values.

This consistency permits to calculate partition coefficients $D$ of elements between plagioclase and magma $\left(D_{\text {plag }}\right.$ $=C_{\text {plag }} / C_{\text {liquid }}, C$ being the concentration of the element). One can indeed postulate that, in view of their homogeneity, the phenocrysts have crystallized in equilibrium with a parental magmatic liquid. This liquid has been recognized in the border rock (chilled margin) of the Hidra body [33] in which the REE distribution does not show an Eu anomaly (see below). Values of $D_{\text {plag }}$ determined by this method (Table 2) are in close agreement with values reported in the literature for similar anorthite contents of the plagioclase (e.g. [42-44]), except for K

\footnotetext{
* A data compilation and detailed calculations for the modelling of the Bjerkrem-Sogndal and Hidra bodies are available on request.
} 
(and $\mathrm{Rb}$, see below) where our values are significantly higher. We shall see below that high values for $D_{\text {plag }}^{\mathrm{K}}$ and $D_{\text {plag }}^{\mathrm{Rb}}$ are confirmed by the quantitative modelling. Introduced into equations of fractional crystallization, they permit calculation of internally consistent models to justify the observed $\mathrm{K}-\mathrm{Rb}$ relations. These high values could either reflect a pressure effect, as suggested by Griffin et al. [37] or the influence of the bulk composition of the liquid.

Fig. 2. Plot of Sr vs. Ca in plagioclase from anorthosites and related rocks.

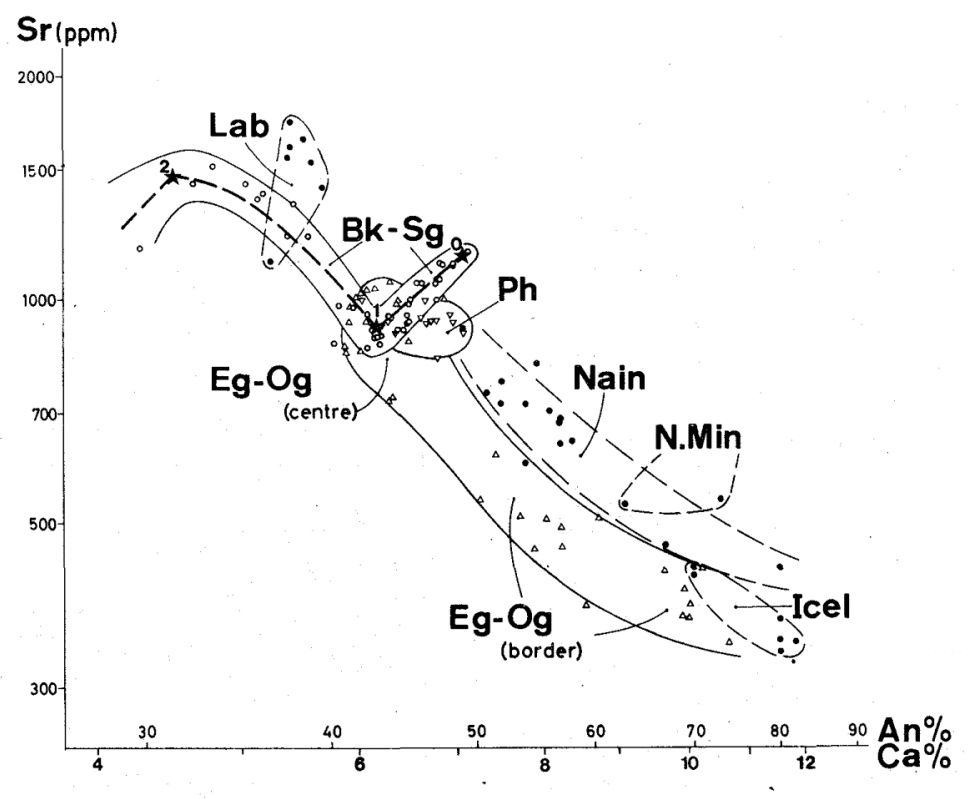

Bk-Sg = Bjerkrem-Sogndal lopolith; Eg-Og (centre) = central part of the Egersund-Ogna body; Eg-Og (border) = inner border of the Egersund-Ogna body $; \mathrm{Ph}=$ phenocrysts from different Rogaland bodies; Lab = Labrieville [36] ; Nain = Nain complex [35] ; N. Minn, Icel $=$ North Minnesota and Iceland anorthositic inclusions [37]. o = Bjerkrem-Sogndal plagioclases; $\Delta=$ Egersund-Ogna plagioclases; $\nabla=$ phenocrysts; $\boldsymbol{\nabla}=$ average phenocrysts from Åna-Sira body (R. Zeino-Mahmalat, personal communication, 1975); $\bullet$ = plagioclases outside Rogaland bodies. In Bjerkrem-Sogndal, points 0,1 and 2 (stars) refer to calculated plagioclases in equilibrium with the parental magma and the liquids at the end of the anorthositic-leuconoritic and noritic stages. Between 1 and 2 the evolution is not linear because of the strong variation of $D_{\mathrm{plag}}^{\mathrm{Sr}}$ at this stage.

TABLE 1. Average contents and standard deviations in andesine plagioclase

\begin{tabular}{|l|l|l|l|l|l|}
\hline & $\begin{array}{l}\text { Number of } \\
\text { samples }\end{array}$ & $\mathrm{Ca}(\%)$ & $\mathrm{Sr}(\mathrm{ppm})$ & $\mathrm{K}(\%)$ & $\mathrm{Ba}(\mathrm{ppm})$ \\
\hline Megacrysts & & & & & \\
\hline Intermassif average & 15 & $6.72 \pm 0.28$ & $933 \pm 32$ & $0.53 \pm 0.1$ & $173 \pm 32$ \\
\hline Åna-Sira body * & 17 & $6.40 \pm 0.32$ & $899 \pm 42$ & $0.61 \pm 0.06$ & $250 \pm 45$ \\
\hline Matrix plagioclases & & & & & $288 \pm 44$ \\
\hline Åna-Sira body * & 107 & $6.44 \pm 0.48$ & $901 \pm 40$ & $0.56 \pm 0.08$ & 2 \\
\hline
\end{tabular}

From R. Zeino-Mahmalat (personal communication, 1975).

TABLE 2. Partition coefficients and standard deviations for andesine plagioclase $\left(A n_{47}\right)$

\begin{tabular}{|l|l|l|l|}
\hline Sr & $\mathrm{Ca}$ & $\mathrm{K}$ & $\mathrm{Ba}$ \\
\hline $2.3 \pm 0.2$ & $1.48 \pm 0.04$ & $0.47 \pm 0.05$ & $0.39 \pm 0.07$ \\
\hline
\end{tabular}

Note: The values are obtained through dividing the contents of the megacrysts (see Table 1) by the average contents of the corresponding elements in jotunitic liquids of the chilled margins of the Hidra body ([33], and new data). 
Fig. 3. Plot of Ba vs. K in plagioclase. Symbols and data sources as in Fig. 2.

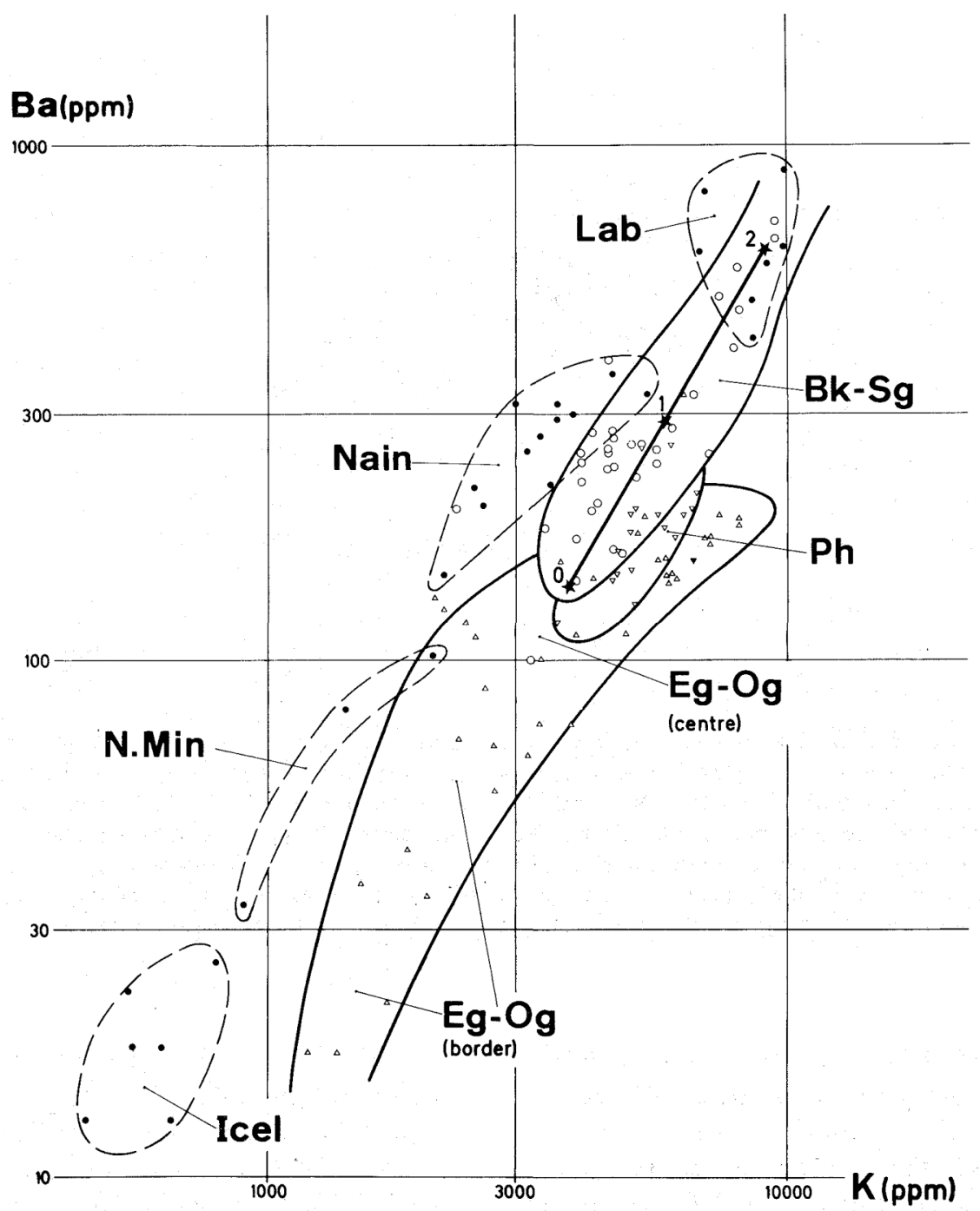

\subsection{Modelling of the Bjerkrem-Sogndal lopolith}

The evolution of $\mathrm{Sr}$ and $\mathrm{Ca}$ contents in the Bjerkrem-Sogndal plagioclases can be explained by a fractional crystallization process. A qualitative model has been developed earlier [39]. Determination of partition coefficients now allows a quantitative approach. Details will be published elsewhere ; only the more important points are presented here.

Concentration $C$ of an element in a magma of initial concentration $C_{0}$ which fractionates according to the Rayleigh logarithmic model can be expressed by the following equation:

$$
C=C_{0} f^{D-1}
$$

in which $f$ is the fraction of residual liquid, $D$ is the bulk partition coefficient. If $\mu_{i}$. is the fraction (by weight) of the rock composed of mineral $i$ and $D_{i}$ the partition coefficient of the element in mineral ${ }_{\mathrm{i}}$, then:

$$
D=\sum_{i} \mu_{i} D_{i}
$$


In a bi-logarithmic diagram in which concentrations $C_{A}$ and $C_{B}$ of two elements $A$ and $B$ are plotted, the evolution of $C_{A}$ and $C_{B}$ in the liquid (or in the solid) can be represented by a straight line with a slope $\left(D^{A}-1\right) /$ $\left(D^{B}-1\right)$, provided $D^{A}$ and $D^{B}$ do not vary (see also Treuil and Joron [45]).

The Sr-Ca diagram for Bjerkrem-Sogndal (Fig. 2) can be split into three trends which correspond to successive steps in the crystallization of the anorthositic-noritic phase. Each trend can roughly be approximated by a straight line, which permits to think that the differentiation mechanism is controlled by the Rayleigh model. Changes in slope are due to change in the nature and proportions of cumulate minerals (discontinuous cryptic layering of Wager and Brown [46]).

Starting from the highest Ca content, the following succession is inferred: (1) a trend with a positive slope, which corresponds to the crystallization of anorthosites and leuconorites in which the assemblage is plagioclase $\left(\mathrm{An}_{50-43}\right)+$ orthopyroxene + oxides; (2) a trend with a negative slope, which corresponds to the crystallization of the norites; the change in the slope is due to the appearance of clino-pyroxene and apatite as additional cumulate minerals; plagioclase is $\mathrm{An}_{43-31}$; and (3) a second trend with a positive slope, which characterizes the plagioclase of rocks transitional towards acidic rocks which contain mesoperthitic feldspars, lower in $\mathrm{Sr}$ and Ca contents (not plotted in Fig. 2); the change of slope is now due to the appearance of K-feldspar.

The parameters of the model which best fit the three trends are the following: (1) at the end of the first trend, $f=$ 0.47 and the average cumulate is made of $74 \%$ plagioclase $+16 \%$ orthopyroxene $+10 \%$ oxides; and (2) at the end of the second trend, $f=0.21$ and the average noritic cumulate is $45 \%$ plagioclase $+22 \%$ orthopyroxene + $9 \%$ clinopyroxene $+4 \%$ apatite $+20 \%$ oxides.

Values of the parameters are obtained by iterative method of optimalization starting from measured values of $D_{i}$, determination of distribution coefficients of elements between cumulus minerals and determination of average modal (or normative) composition of the rocks. It is necessary to allow $D_{\text {plag }}^{\mathrm{Sr}}$ to increase with the decrease in the An content of the plagioclase, a variation which is well known from the work of Philpotts and Schnetzler [42].

\subsection{The Egersund-Ogna body}

Plagioclases of the meta-leuconorites (and, locally, meta-troctolites) which constitute the inner border of the massif are labradoritic and impoverished in $\mathrm{Sr}, \mathrm{K}$ and $\mathrm{Ba}$. A continuous variation exists between these plagioclases and the andesinic Sr-rich plagioclases of the central part (Fig. 2). The occurrence of basic plagioclases in the border rocks would support the hypothesis of a crystallization process beginning at the periphery of the massif and spreading toward the centre. Inward cooling of the magmatic chamber is, however, unable to explain the following points:

(1) The increase of Sr during crystallization implies a value of the bulk coefficient $D^{\mathrm{Sr}}$ less than unity. In the Bjerkrem-Sogndal lopolith this condition is realized in the norites by precipitation of apatite and clinopyroxene. In the Egersund-Ogna massif, on the contrary, these two minerals do not belong to the mineral association. The latter is approximately $80 \%$ plagioclase $+20 \%$ orthopyroxene in the border rocks and, consequently, a $D^{\mathrm{Sr}}$ less than unity can only be realized if $D_{\text {plag }}^{\mathrm{Sr}}$ is also less than unity. $D_{\text {plag }}^{\mathrm{Sr}}$ decreases with the An content of the plagioclase [42] but values smaller than 1 are not reported in the literature for labradoritic plagioclase. Moreover, the increase of $\mathrm{Sr}$ is also apparent for a variation of the An content in the interval $\mathrm{An}_{50}$ to $\mathrm{An}_{40}$; but the $D_{\text {plag }}^{\mathrm{Sr}}$ value found in the Bjerkrem-Sogndal lopolith for this range of composition is higher than 2.

(2) Preliminary REE determinations [47] show that plagioclases from the border are roughly 2 times richer than those from the central part, which would indicate (see below) an outward fractionation.

(3) In the anorthositic suite, fractional crystallization leads to an enrichment in the proportion of the mafic minerals, a trend opposite to the observed one.

It can thus be concluded that an inward fractional crystallization model does not satisfy the geochemical constraints. More complex processes which could have acted in conjunction with fractional crystallization must be tested. Among others, the following factors must be considered: the influence of the metamorphic recrystallization of the border rocks, the possibility of interaction with the surrounding gneisses (see section 6), the possibility of a high-pressure stage of crystallization as suggested by plagioclase exsolutions in "giant" orthopyroxenes [27] and the influence of these high pressures on the composition of the liquidus plagioclase. An 
origin by anatexis of leuconoritic gneisses [31] should also be tested as well as the hypothesis of crystallization of clinopyroxene and/or apatite together with plagioclase and orthopyroxene (in such a way that $D^{\mathrm{Sr}}$ be $<1$ and $D^{\mathrm{REE}}>1$ ), the former minerals being segregated and remaining at depth. The similarities between the $\mathrm{Sr}-\mathrm{Ca}$ trends in the Egersund-Ogna body and in the Nain complex (Fig. 2) as well as the identical nature of the mafic mineral (olivine and/or orthopyroxene) which coexist with the plagioclase are worth being emphasized and must also be considered.

From a more general point of view, deciphering the Egersund-Ogna genetic mechanism thus appears essential to understand the relationships between the two major types of massif anorthosites, the andesine anorthosite and the labradorite anorthosite.

\subsection{Granulation of plagioclase}

Granulation of plagioclase is a frequent phenomenon in massif anorthosites. It results from the deformation of the mineral when the rock is incompletely (protoclasis) or completely solidified (cataclasis). No significant difference (except for Ti, see section 5) is recognizable between major and trace elements in phenocrysts and matrix plagioclases (see Fig. 2). Data on Åna-Sira plagioclases also confirm this observation ([40]; Table 1).

It thus appears that deformation and subsequent recrystallization can occur without modifying the $\mathrm{Sr}, \mathrm{Ca}, \mathrm{Ba}$ and $\mathrm{K}$ geochemistry of the plagioclase. If the granulation is protoclastic, this implies that the partition coefficients between solid and liquid are little influenced by temperature variations or, should the case arise, by pressure differences.

\subsection{Conclusions}

The $\mathrm{Sr}, \mathrm{Ba}, \mathrm{Ca}$ and $\mathrm{K}$ contents in plagioclase prove to be interesting tools to study petrogenetic mechanisms. It permits to test the hypothesis of the consanguinity by fractional crystallization of anorthosites, leuconorites and norites. It shows a great uniformity in the composition of andesine phenocrysts and no significant difference between phenocrysts and granulated minerals. It stresses the peculiarities of the relationship between labradorite and andesine anorthosites and assesses the constraints with which a petrogenetic model, still to be defined, must comply. It shows the existence of a large interval of trace element variations. This interval is wider than that which can be explained in Bjerkrem-Sogndal by differentiation of a single magmatic liquid. It can thus be concluded that several magmas of different compositions are likely to play a role in the petrogenesis of massif anorthosites.

\section{Potassium and rubidium}

Data available in the literature are plotted in Fig. 4 in which is also presented the "main trend" defined by Shaw [48] for magmatic rocks. The first study on the $\mathrm{K} / \mathrm{Rb}$ ratio in the anorthositic suite is due to Reynolds et al. [50], who have demonstrated the progressive variation of $\mathrm{K}$ and $\mathrm{Rb}$ contents from anorthosites to acidic rocks. These authors, however, failed to decide between a mixing process or magmatic differentiation to explain the observed trend; they interpreted the high $\mathrm{K} / \mathrm{Rb}$ values in anorthosites as indicating a mantle or a deep crustal origin without noticing, as Murthy and Griffin [36] did, that this ratio is essentially controlled by plagioclase ; they also showed that $\mathrm{K} / \mathrm{Rb}$ ratios in acidic rocks are higher than the crustal average. This peculiarity was later confirmed by Green et al. [49] who considered these rocks as residual product of partial fusion of the crust. They thus considered a genetic relationship between mangerite and anorthosite as unlikely. Data on the Nain complex are given by Gill and Murthy [35]. Griffin et al. [37] give values for the Labrieville body and some other occurrences with which they define an intermassif trend which is opposite to that previously obtained by Murthy and Griffin [36].

\subsection{Rogaland data}

Available data for the Rogaland are presented in Fig. 5 in which data from Griffin et al. [37] on rocks of this province and from Zeino-Mahmalat [40] on the Åna-Sira massif are also included.

The range of variation of the $\mathrm{Rb}$ content is particularly wide : less than $1 \mathrm{ppm}$ in plagioclase from the EgersundOgna border to $0.1 \%$ in Hidra pegmatite. Variations of the $\mathrm{K} / \mathrm{Rb}$ ratio are also important: more than 8000 in some Bjerkrem-Sogndal plagioclases, less than 100 in acidic rocks. The characteristics already mentioned in 
previous work are found here : high $\mathrm{K} / \mathrm{Rb}$ ratios in anorthosite and progressive decrease of the ratio in the different terms of the series (jotunite, mangerite and quartz mangerite).

On the scale of the massifs, two peculiar trends can be clearly defined: (1) in the Hidra body (Fig. 7) the points fall into a linear trend, nearly parallel to Shaw's main trend; and (2) in the Bjerkrem-Sogndal lopolith (Fig. 6) the points representing the mangerites and quartz mangerites plot on a linear trend which cross-cuts Shaw's main trend; moreover it is to be noted that this trend is prolonged by points representing gneisses and granites of the envelope, which have low $\mathrm{K} / \mathrm{Rb}$ ratios.

Existence of linear trends in bi-logarithmic diagrams permits to identify fractional crystallization as the controlling mechanism for the Hidra and Bjerkrem-Sogndal bodies.

In Bjerkrem-Sogndal (Fig. 6), the parameters defined in modelling the Sr-Ca and Ba-K behaviours, the values of $D_{\text {plag }}^{\mathrm{Rb}}$ and $D_{\mathrm{Or}}^{\mathrm{Rb}}$ (Table 3 ) have been introduced into the Rayleigh equation. It follows the position and slope of the broken line representing the evolution of the liquids (Fig. 6).

In Hidra (Fig. 7), the proportions and the modes of the different rock types as well as the composition of the liquid of the chilled margin are taken into account in the modelling, which also leads to a satisfying representation of the liquid evolution and of cumulates in equilibrium with the liquids. In these two models it is necessary to allow for a slight variation of the partition coefficients with the An content of the plagioclase (Table $3)$.

Fig. 4. Plot of $K$ vs. Rb in rocks and plagioclases from the anorthositic suite.

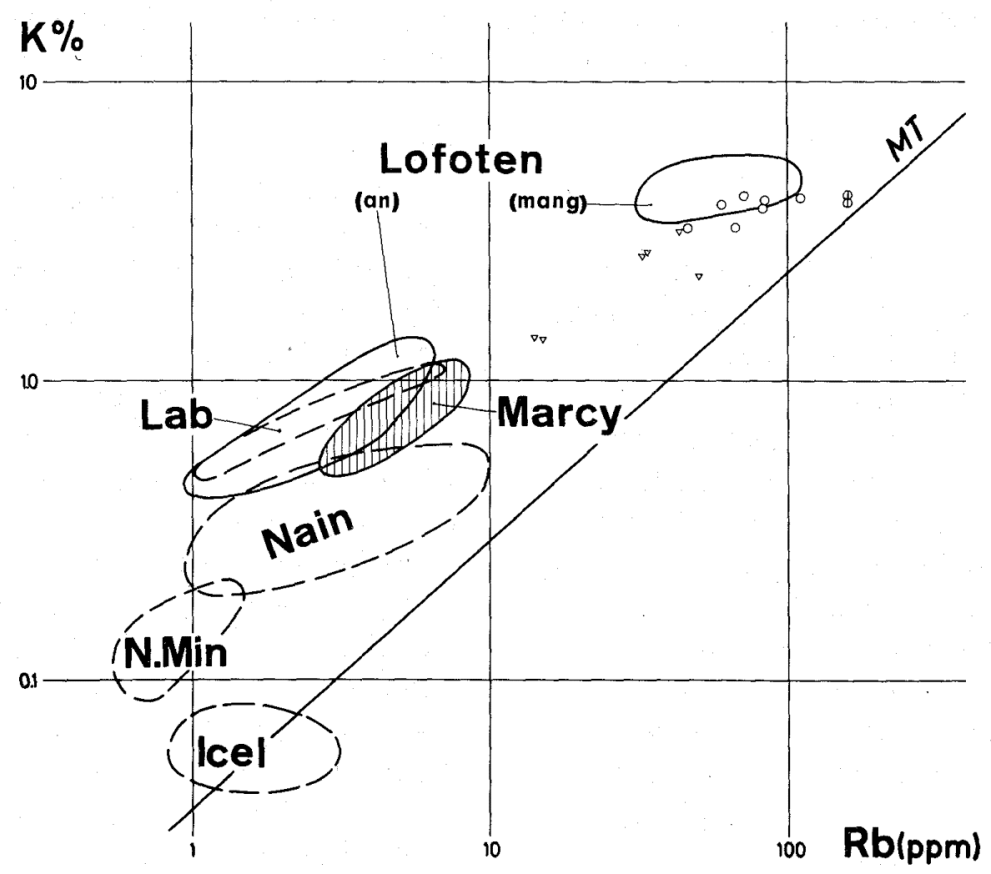

Data for plagioclases from the following sources: North Minnesota, Iceland and Labrieville from Griffin et al. [37] ; Nain from Gill and Murthy [35]. Data for whole rocks: Lofoten from Green et al. [49], (an) = anorthosite; (mang) = mangerite; Marcy from Reynolds et al. [50] ; jotunite $(\nabla)$, mangerite $(\bigcirc)$ and gneiss $(\Phi)$ of Snowy Mountain, Adirondacks, from Reynolds et al. [50]. The main trend of Shaw [48] (MT) describes the $\mathrm{K}-\mathrm{Rb}$ fractionation in average magmatic rocks.

\subsection{Conclusions}

Modelling of $\mathrm{K}$ and $\mathrm{Rb}$ in the two massifs, when considered within the whole data of the province, leads to the following conclusions :

(1) Potassium and Rb contents of parental liquids drawn from modelling (Bjerkrem-Sogndal) or confirmed by it (Hidra) are typical of jotunitic liquids. 
Fig. 5. Plot of $K$ vs. Rb in Rogaland rocks and plagioclases.

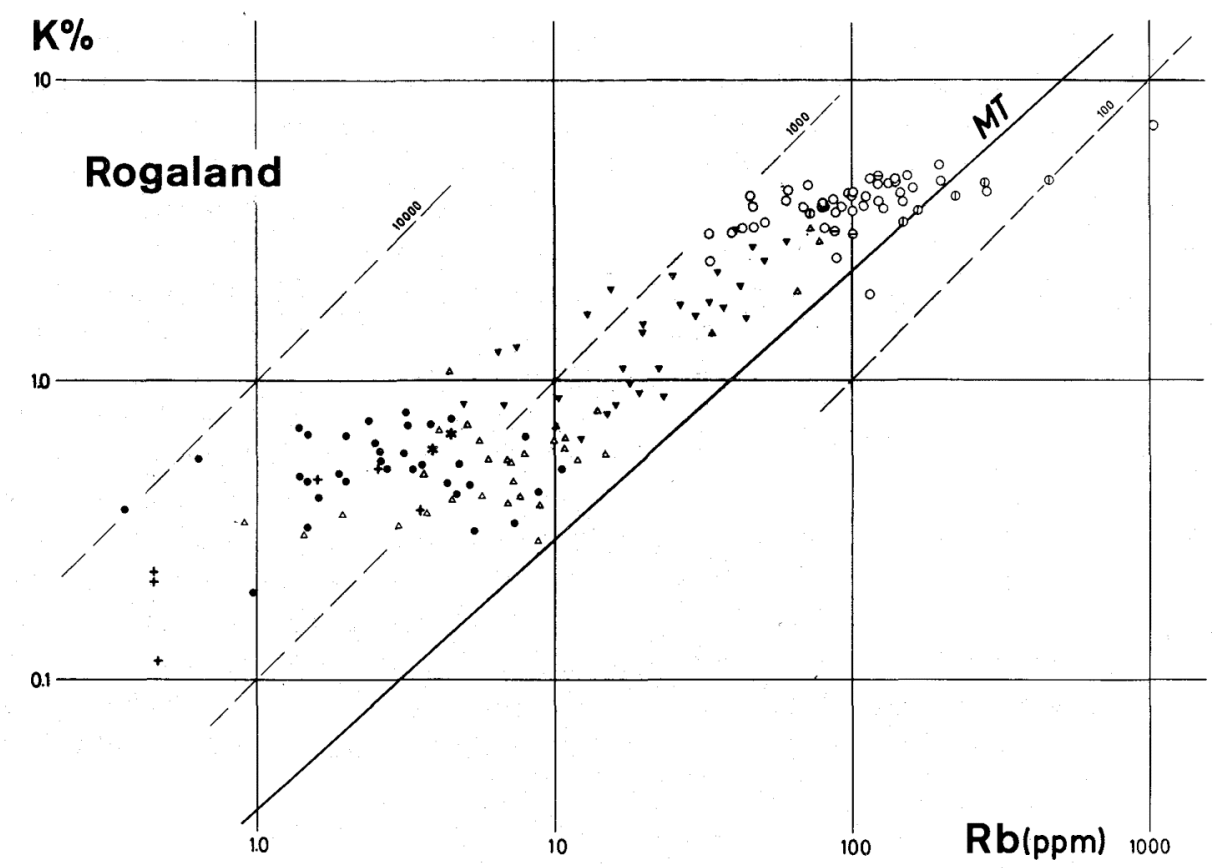

$\Phi=$ surrounding acidic gneiss; $\ominus=$ farsundite; $\bigcirc=$ mangerites and quartz mangerites; $\boldsymbol{\nabla}=$ jotunitic rocks; $\triangle=$ anorthositic and leuconoritic rocks; $\bullet$ = plagioclases from Bjerkrem-Sogndal, Egersund-Ogna (centre), Hidra and Helleren; + = plagioclases from EgersundOgna border; * = average phenocryst and matrix plagioclases from Åna-Sira (R. Zeino-Mahmalat, personal communication, 1975). MT = main trend of Shaw [48]. 100, 1000 and $10000=$ curves of constant $\mathrm{K} / \mathrm{Rb}$ ratio.

(2) The $\mathrm{K} / \mathrm{Rb}$ ratios in these parental liquids are, however, not identical: values of 480 and 790 are found in Hidra and in Bjerkrem-Sogndal, respectively. Still higher values are found in other jotunitic rocks (Fig. 5) occurring for instance in the Eia-Rekefjord intrusion where values of 1700 have been reported [33]. These high $\mathrm{K} / \mathrm{Rb}$ values cannot be explained by fractional crystallization of a unique liquid. It is indeed obvious that the slope $\left(D^{\mathrm{K}}-1\right) /\left(D^{\mathrm{Rb}}-1\right)$ will never be higher than 1 because $D^{\mathrm{K}}>D^{\mathrm{Rb}}$, whatever the mineralogy of the cumulate might be.

It can thus be assessed that the variations of $\mathrm{K} / \mathrm{Rb}$ ratios are due to the process of magma formation and therefore the constraints must refer to this level;

(3) The overall trends of the $\mathrm{K} / \mathrm{Rb}$ relationships (Figs. 4 and 5) in anorthosites, norites and jotunites can be simply explained hy fractional crystallization of liquids of variable $\mathrm{K} / \mathrm{Rb}$ ratio. Acidic rocks can also be explained by the same process. However, as granitic gneisses of the envelope also plot on the same trend, one cannot reject the possibility of a mixing process by assimilation or hybridization between the late-stage liquids and the gneisses and modelling does not solve the petrogenetic dilemma.

(4) As in the case of $\mathrm{Sr}, \mathrm{Ca}, \mathrm{Ba}$ and $\mathrm{K}$, the wide variation of $\mathrm{Rb}$ between the different massifs would indicate parental liquids of variable $\mathrm{Rb}$ contents. 
Fig. 6. Plot of $K$ vs. Rb in the Bjerkrem-Sogndal lopolith.

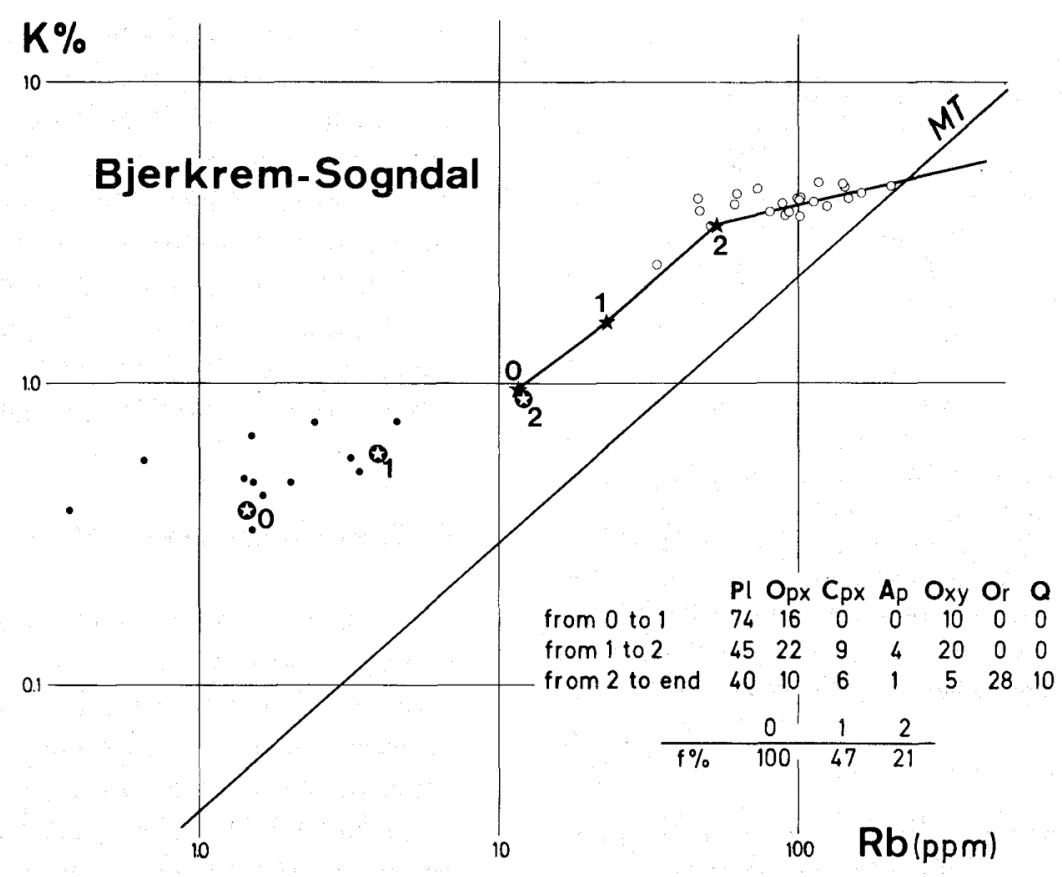

$\bullet$ = plagioclases; $\bigcirc=$ acidic rocks; $\star$ = calculated magmatic liquids; 7 = calculated cumulate plagioclases in equilibrium with the liquids at stages of fractionation 0,1 and 2. Evolution of the liquids represented by the broken line passing through the black stars. Modal proportions in the average cumulates formed in the successive stages of crystallization are indicated on the figure.

Fig. 7. Plot of K vs. Rb in the Hidra body. Symbols and indications as in Figs. 5 and 6.

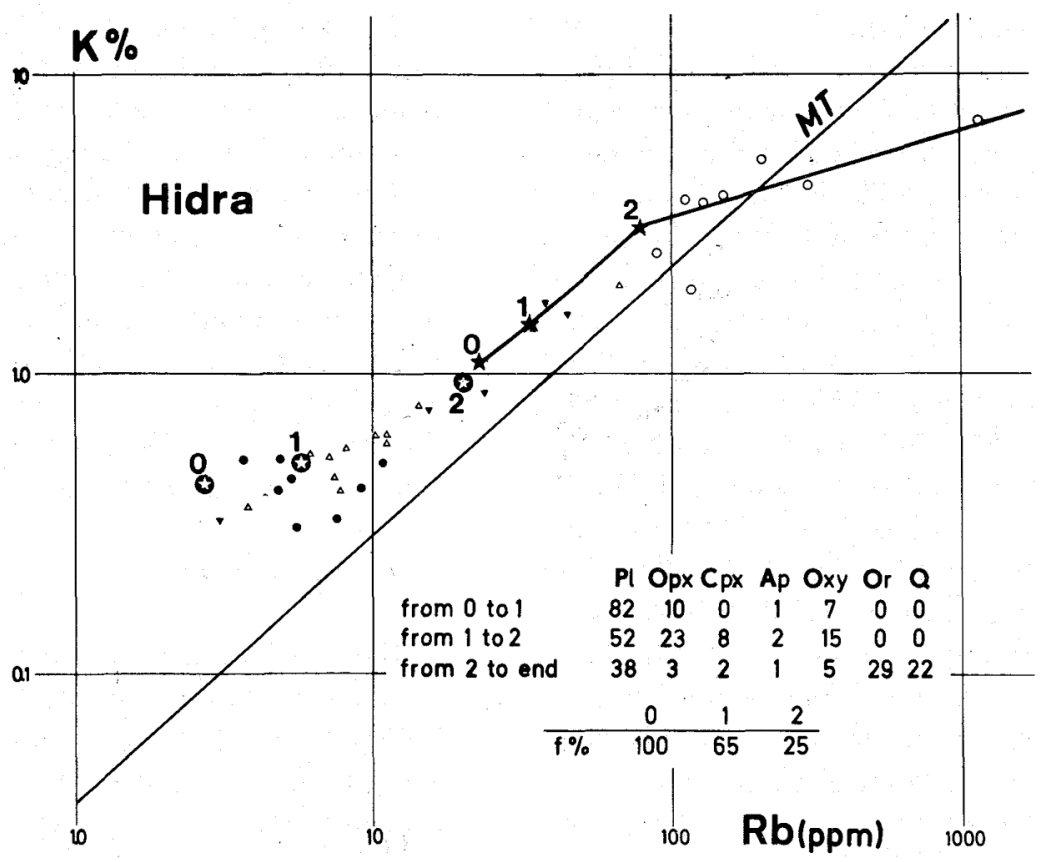


TABLE 3. Partition coefficients adopted for $K$ and $R b$

\begin{tabular}{|l|l|l|}
\hline & $D^{\mathrm{K}}$ & $D^{\mathrm{Rb}}$ \\
\hline Plagioclase & & \\
\hline $\mathrm{An}_{50}$ & 0.40 & 0.12 \\
\hline $\mathrm{An}_{40}$ & 0.35 & 0.17 \\
\hline $\mathrm{An}_{20}$ & 0.29 & 0.25 \\
\hline K-feldspar (Or) & 2.4 & 0.8 \\
\hline
\end{tabular}

Note: $D_{\text {plag }}^{\mathrm{K}}$ is taken from Table 2 and modified in function of the anorthite variation so as to give the model which best fits the data. $D_{\text {plag }}^{\mathrm{Rb}}$ has also been adapted in a similar way, starting from a rough approximation of its value $(0.15 \pm 0.06)$, obtained from a few measurements of $\mathrm{Rb}$ on megacrysts and rocks of chilled margins. $D_{O r}^{K}$ and $D_{O r}^{R b}$ are taken from Dupuy and Allègre [43], the former being slightly modified.

\section{Rare earth elements}

From the study of an anorthosite and quartz mangerite, Philpotts et al. [51] have demonstrated the cumulate character of the former and the similarity between the latter and a composite sample of North American shale, especially with respect to the absence of an Eu anomaly. They concluded that the two rocks belong to different series and that an assimilation process explains the distribution in the quartz mangerite.

Mangerites from the Lofoten Islands [49] show a positive Eu anomaly which would result from feldspar accumulation or be produced by fusion involving feldspar of the residue of a previous anatexis, as the high $\mathrm{K} / \mathrm{Rb}$ ratios would also indicate. Moreover, Green et al. [49] are unable to decide between an intermediate (dioritic) and a basic nature of the parental magma, or between different processes of formation of the dioritic magma.

Griffin et al. [37] have analyzed plagioclases from different massifs and, using available partition coefficients, determined the compositions of parental liquids in equilibrium with them (Fig. 9). For a decreasing An content of the plagioclase they established a gross increase in the REE content and in the fractionation of REE, beginning with a distribution similar to ocean tholeiite.

\subsection{Rogaland data}

Rare earth elements are at present being studied in Rogaland rocks and minerals. Preliminary results have been published [33] and complementary data have been obtained since, mainly from Bjerkrem-Sogndal and Hidra. Only a first tentative interpretation is given here, detailed data will be presented elsewhere.

4.1.1. Bjerkrem-Sogndal and Hidra bodies The REE contents have been determined by neutron activation analysis [47] on pairs of plagioclases and apatites separated from several rocks taken at three different levels in the zone where apatite occurs as a cumulate mineral [52]. Average values obtained for each level are plotted in Fig. 8. The proportion of residual liquid (i.e. factor $f$ in equation 1) in equilibrium with each pair of minerals can be estimated from the Sr-Ca modelling. Association 1 in Fig. 8 corresponds to the first appearance of apatite + clinopyroxene and thus coincides with the beginning of the negative slope trend (see Fig. 2), i.e. $f=0.47$; association 3 approximately corresponds to the end of the noritic phase, i.e. $f=0.21$. In between these two levels the REE enrichment is of a factor 2.20 .

Assuming that the REE (except Eu) behave in fractional crystallization like hygromagmatophile elements, that is with a partition coefficient negligible relatively to 1 [45], Rayleigh's equation can be written :

\section{$C / C_{0}=1 / f$}

It follows that, between 1 and 3, the concentration ratio in the liquid or in the solids which are in equilibrium with it is $C_{3} / C_{1}=f_{1} / f_{3}$. The $f_{1} / f_{3}$ ratio value is 2.24 . The excellent agreement between this value and the 
enrichment factor in apatites shows that the hypothesis of a hygromagmatophile behaviour of the REE is valid.

Fig. 8. Chondrite-normalized REE patterns in coexisting pairs of apatite and plagioclase at three different levels of the Bjerkrem-Sogndal massif. Parental liquid (0) and successive liquids $(1,2,3)$ calculated by quantitative modelling (see text).

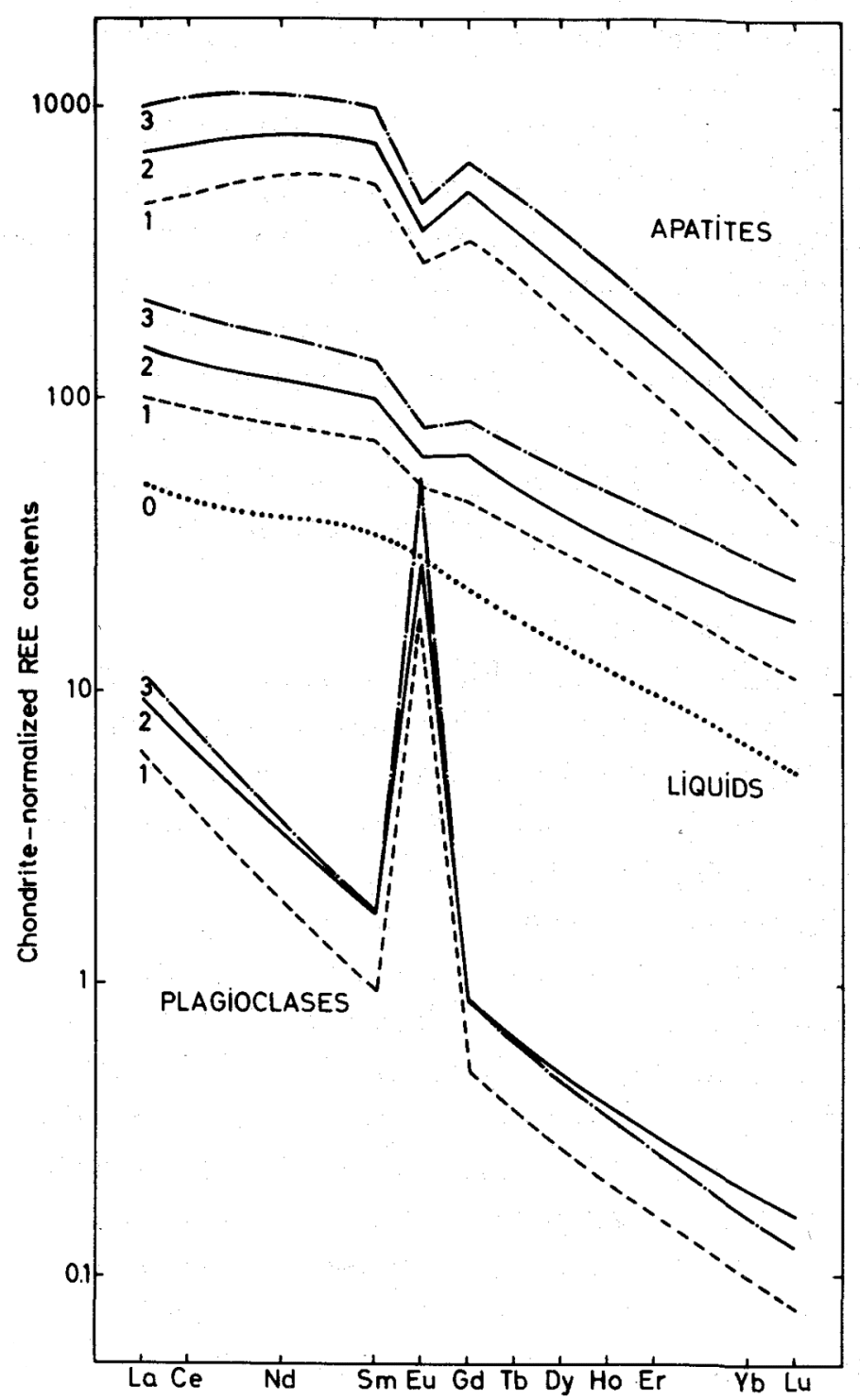

This REE characteristic permits to fix an upper limit to the value of the partition coefficient in apatite, $D_{\text {apat }}$. It demands a bulk partition coefficient not higher than 0.2 [45]. As $D=\Sigma_{i} \mu_{i} D_{i}$ and the apatite content $\left(\mu_{i}\right)$ in the noritic phase is $4 \%, D_{\text {apat }}$ must be equal to or less than 5 . Provisional values equal to half the values calculated for the Skaergaard by Paster et al. [53] are chosen. As $D_{\text {apat }} / D_{\text {plag }}$ is constant, these values lead to $D$ values very similar to those adopted by these authors for the plagioclase and the other minerals.

It also results from the hygromagmatophile character that the REE distribution in successive liquids is not modified by fractional crystallization. The $\mathrm{La} / \mathrm{Yb}$ ratio in liquids and cumulate minerals thus remains constant.

Given the partition coefficients of the apatite it is possible to calculate the REE contents in liquids at stages 1 and 3 and, starting from one of these liquids, to determine the distribution in the parental liquid (Fig. 9). Note that in the calculation of the parental liquid, the hypothesis of a hygromagmatophile behaviour for the REE is quite plausible. Indeed, the minerals which crystallize between the beginning of the differentiation and the appearance of the apatite, namely plagioclase, orthopyroxene and oxides, have very low $D_{i}$.

Europium cannot be considered as hygromagmatophile in plagioclase-rich rocks because its partition coefficient 
in plagioclase is too high. It can be easily demonstrated that if the parental magma has no Eu anomaly, the Eu anomalies observed in liquids 1 and 3, for values of/equal to 0.47 and 0.21 respectively, can be explained by a value of $D_{\text {plag }}^{\mathrm{Eu}}$ varying during crystallization from 0.26 to 0.64 . The increase is parallel to that of $D_{\mathrm{plag}}^{\mathrm{Sr}}, \mathrm{Eu}^{2+}$ and Sr having similar behaviour. The increase in the $\mathrm{Eu}^{2+}$ proportion is simultaneous with a decrease in the fugacity of oxygen, which has been demonstrated in the course of crystallization of the massif [29]. The $\mathrm{Eu}^{3+} / \mathrm{Eu}^{2}$ ratio in the magma can be calculated using the method suggested by Philpotts [54] and Jensen [55] : it varies from $80 \%$ at the beginning to $60 \%$ at the stage 3, ratios which, according to Jensen [55], fall well within terrestrial values.

Fig. 9. Chondrite-normalized REE patterns in different parental liquids.

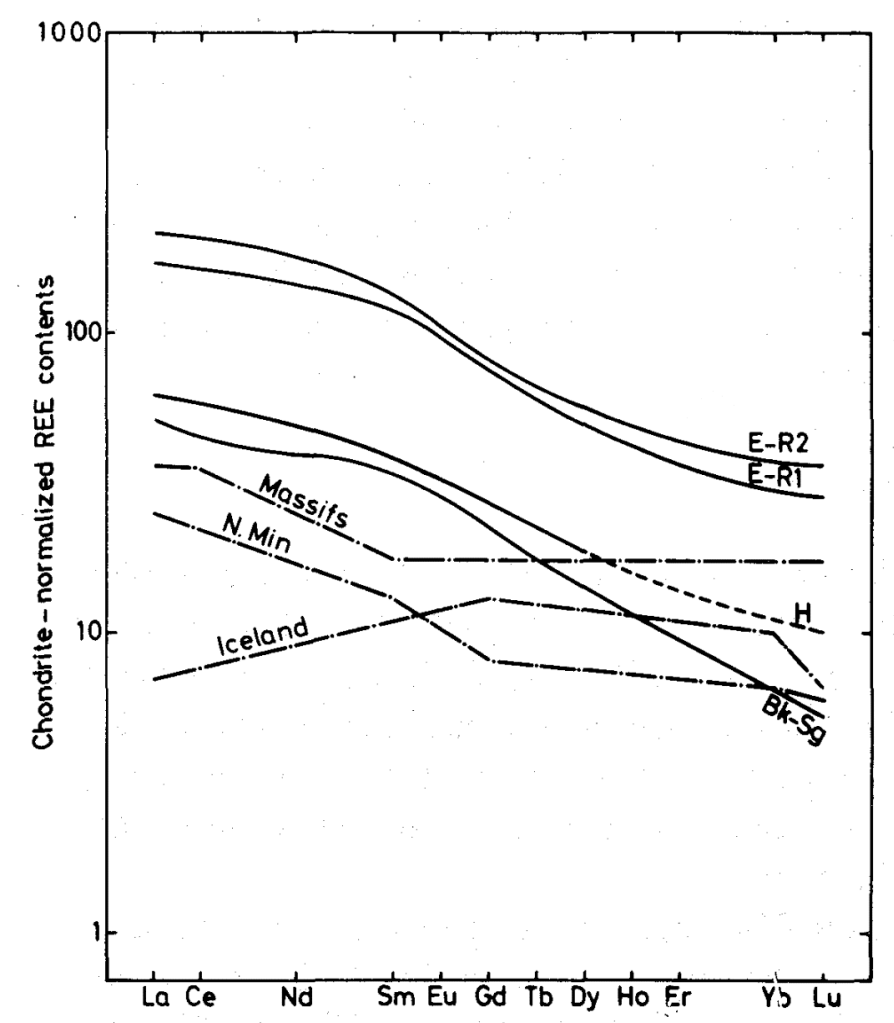

Bk-Sg = Bjerkrem-Sogndal lopolith; $\mathrm{H}=$ Hidra body $;$ E-R1, E-R 2 = Eia-Rekefjord intrusion [33]. Iceland, N. Minn, and Massifs = liquids calculated by Griffin et al. [37] for Iceland and North Minnesota anorthositic inclusions and Norvegian massif anorthosites, respectively.

The REE behaviour in the anorthositic-noritic phase of the Bjerkrem-Sogndal lopolith can thus be described by the same model as the one constructed for $\mathrm{Sr}, \mathrm{Ca}, \mathrm{Ba}, \mathrm{K}$ and $\mathrm{Rb}$.

As for the acidic rocks of the massif, the origin of which will be dealt with below, it must already be noted that some quartz mangerites, which are vol-umetrically important in the upper part of the lopolith, have REE contents, a $\mathrm{La} / \mathrm{Yb}$ ratio and an Eu anomaly very similar to those of liquid 3, at the end of the noritic phase. Direct derivation of these rocks by fractional crystallization is thus plausible.

In the Hidra body, $\mathrm{REE}^{*}$ evolution can also be described assuming the REE are hygromagmatophile. The parental magma represented by rocks of the chilled margin with no Eu anomaly [33] gives rise, for a value of 0.30 , to the acidic material of the dykes which inject the leuconorite. This inference is in good agreement with the $\mathrm{K}$ and $\mathrm{Rb}$ model. The Eu anomaly in the dykes implies a $D_{\mathrm{plag}}^{\mathrm{Eu}}=0.7$, which would indicate a lower $f_{\mathrm{O}_{2}}$

\footnotetext{
${ }^{*}$ REE determination by instrumental neutron activation analysis (J. Hertogen, personal communication, 1975).
} 
value in Hidra than in Bjerkrem-Sogndal.

Parental liquids of Bjerkrem-Sogndal and Hidra are represented in Fig. 9 together with presumed parental liquids of jotunitic character which were identifie in rocks of the Eia-Rekefjord intrusion [33]. They grossly show parallel trends, but with variable contents from massif to massif. The Bjerkrem-Sogndal and Hidra magmas are rather comparable to those schematically calculated by Griffin et al. [37] for the parental liquid of massif-type anorthosites.

\subsubsection{Acidic rocks}

The REE contents in Bjerkrem-Sogndal quartz mangeritic rocks vary within a range of values represented in Fig. 10, The Lyngdal hornblende-granodiorite, the Farsund charnockite and the Hidra dykes also fall within the same interval.

The Bjerkrem-Sogndal quartz mangerites show a negative Eu anomaly and can thus be considered as residual liquids left by crystallization of plagioclase-rich cumulates (anorthositic-noritic phase). The REE contents, however, vary in the opposite way from the differentiation index of the rocks [58]. It can thus be inferred that the genetic process cannot be described by the fractionation mechanism used for the lower part of the massif. The hypothesis of a mixing by assimilation or hybridization with material from the envelope is to be considered since it appears plausible for $\mathrm{K}$ and $\mathrm{Rb}$ and for the $\mathrm{Sr}$ isotopic compositions (see below). The REE in gneisses of the metamorphic envelope are still little known; a single analysis is available (L. Franssen, personal communication, 1975) (Fig. 10). If, however, the average value obtained on Precambrian sediments [56] (Fig. 10) can be considered as representative of the material contaminating the Bjerkrem-Sogndal late-stage liquids, the mixing

Fig. 10. Chondrite-normalized REE patterns in acidic rocks.

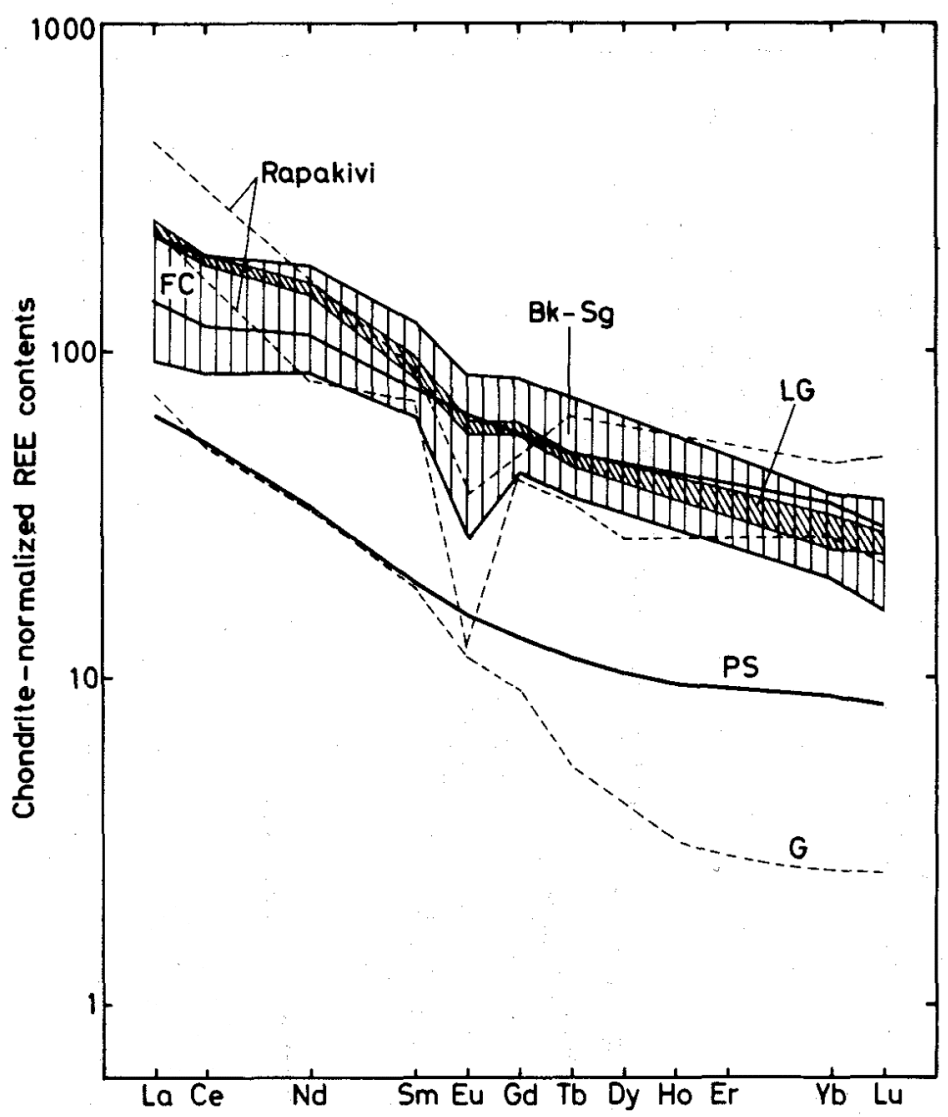

Bk-Sg (vertically hatched $)=$ range of quartz mangerites, LG (diagonally hatched) $=$ range of Lyngdal hornblende-grano-diorite; FC = Farsund charnockite; PS = average of 36 Pre-cambrian shales [56], G= Rogaland surrounding gneiss (L. Franssen, personal communication, 1975); Rapakivi (between the two dashed lines) = Finnish Rapakivi granites [57]. 
hypothesis is plausible for the REE also. The range of REE contents in quartz mangerites is situated between the distribution at the end of the anorthositic-noritic phase and the distribution for the average Precambrian sediments.

The Lyngdal hornblende-granodiorite displays a negative Eu anomaly. On the other hand, the Farsund charnockite shows no Eu anomaly. These features are in good agreement with the inference drawn from the ${ }^{87} \mathrm{Sr} /{ }^{86} \mathrm{Sr}$ initial ratios (see below) of an origin by differentiation for the former and by anatexis of gneisses of sedimentary origin for the latter [4,59].

The Finnish Rapakivi granites [57] occupy a range of compositions close to the Rogaland acidic rocks (Fig. 10). It must, however, be noted that they present a stronger Eu anomaly and a higher $\mathrm{La} / \mathrm{Yb}$ ratio. The present data do not rule out a possible genetic relationship with anorthosites.

\subsection{Conclusions}

Rare earth element study in Rogaland permits to identify jotunitic liquids as parental magmas, in good agreement with inferences from field relationships and from other trace element data.

It appears that the parental magmas of the different bodies have different REE contents with almost similar $\mathrm{La} / \mathrm{Yb}$ ratios.

Acidic rocks usually show negative Eu anomalies and could thus represent residual liquids left after the crystallization of the anorthosite-norite series. It is, however, necessary, in some cases, also to invoke a contamination process by a material relatively less rich in REE, to explain the absolute contents and the variations with differentiation.

From a methodological point of view the hygro-magmatophile behaviour of the REE appears to be verified to a good approximation, which allows a simple quantitative modelling.

\section{Transition elements}

The geochemistry of transition elements usefully complements that of the REE because they are concentrated in mafic solid phases and become impoverished in residual liquids.

Allègre et al. [60] have used for the Sc-Zn series a diagram similar to the Coryell and Masuda one for the REE. In this diagram, most of the terrestrial rocks appear impoverished in comparison with chondrites and show a typical W-shaped trend; the troughs correspond to $\mathrm{Cr}$ and $\mathrm{Ni}$, relatively, depleted with respect to their neighbours. During differentiation by fractional crystallization from basic magmas, the absolute abundances decrease and the troughs become deeper.

\subsection{Rogaland data}

The transition element contents of rocks representative of jotunitic liquids show only a slight dispersion for the five samples studied (Fig. 11). There appears a sharp peak for Ti which reflects the characteristic increase of that element in the anorthositic series.

Except for Ti, these jotunites are comparable to andesites and high-alumina basalts $[61,62]$ : the $\mathrm{Ni}$ and $\mathrm{Cr}$ contents are low $(<50 \mathrm{ppm}$ and $<30 \mathrm{ppm}$ respectively), the $\mathrm{Ni} / \mathrm{Co}$ ratio is lower than unity and the $\mathrm{V} / \mathrm{Ni}$ ratio close to 10 .

Transition element contents in minerals can also be used as petrogenetic tracers.

Anorthositic plagioclases are characterized by the presence of numerous inclusions of Fe-Ti oxides; $\mathrm{TiO}_{2}$ contents as high as $0.2 \%$ have been measured in phenocrysts. These elements tend to be expelled during deformation and recrystallization of the plagioclase; this has been well known for a long time (e.g. [63]) and is easily visible under the microscope. The chemical analysis is not reliable due to the difficulty of separating plagioclase completely devoid of primary Fe-Ti oxides. R. Zeino-Mahmalat (personal communication, 1975) gives interesting data related to this problem for the plagioclases of the Åna-Sira massif: a significant difference between primary crystals and products of their recrystallization appears only for Ti (Table 4). When the plagioclase of the matrix is protoclastic, one may imagine that the Ti expelled from the mineral is able to 
concentrate in interstitial magmatic liquids and crystallize eventually as primary ilmenite and/or Ti-magnetite. But, when the recrystallization is due to cataclasis (meta-anorthosite), as the rocks do not necessarily include oxides in their matrix, the system seems open for Ti; some authors (e.g. [64]) think that Ti ores could be locally formed by metasomatic concentration. However, these kinds of ores are still to be discovered. The high Fe and Ti contents in the phenocrysts are related to the abnormally high contents of these elements in parental jotunitic liquids [33].

The transition elements in Fe-Ti oxides are interesting tracers for magmatic differentiation as was demonstrated in Bjerkrem-Sogndal [29]. The ranges of concentrations are reported in Table 5. The $\mathrm{Ni}, \mathrm{Co}, \mathrm{Cr}$ and $\mathrm{V}$ contents generally decrease with differentiation whereas $\mathrm{Zn}$ increases. Major elements and $\mathrm{Mn}$ also show large variations in both minerals but they are mainly controlled by late-stage (deuteric) readjustment phenomena and are not very useful as differentiation tracers.

The study of these elements in Rogaland Ti ore bodies has made it possible to correlate these ores with different stages of the general process of fractional crystallization of anorthositic massifs [65]. From an economic point of view, it is interesting to note that ores formed in advanced stages of differentiation are generally very poor in trace elements, especially $\mathrm{Cr}$ which is particularly poisonous for the industrial use of the ores.

TABLE 4. Trace element contents (ppm) and standard deviations in plagioclases from the Ana-Sira massif (from R. Zeino-Mahmalat, personal communication, 1975)

\begin{tabular}{|l|l|l|l|l|l|}
\hline & $\begin{array}{l}\text { Number of } \\
\text { samples }\end{array}$ & Ti & Fe & Mn & Zn \\
\hline Andesine phenocrysts & 17 & $500 \pm 60$ & $2967 \pm 448$ & $25 \pm 6$ & $23 \pm 10$ \\
\hline Matrix plagioclase & 103 & $303 \pm 133$ & $2665 \pm 650$ & $28 \pm 15$ & $22 \pm 15$ \\
\hline
\end{tabular}

TABLE 5. Trace element contents (ppm) in Fe-Ti oxide minerals in the Bjerkrem-Sogndal massif [29]

\begin{tabular}{|l|l|l|l|l|l|}
\hline & $\mathrm{Ni}$ & $\mathrm{Co}$ & $\mathrm{Cr}$ & $\mathrm{Zn}$ & \\
\hline Ilmenite & 900 to $<30$ & 250 to $<30$ & 1500 to $<30$ & 1100 to $<10$ & - \\
\hline Magnetite & 1200 to $<30$ & 370 to $<30$ & 2200 to $<30$ & 4400 to 100 & 370 to 1800 \\
\hline
\end{tabular}

\section{Strontium isotopic composition}

The study of the Sr isotopic initial ratio $\left({ }^{87} \mathrm{Sr} /{ }^{86} \mathrm{Sr}\right)_{0}$ can throw an interesting light on the anorthosite problem, particularly as criterion of a comagmatic origin for the different terms of the anorthositic series.

\section{1, Previous work}

The main conclusions from the literature can be summarized in three points:

(1) $\mathrm{The}{ }^{87} \mathrm{Sr} /{ }^{86} \mathrm{Sr}$ values are generally low $(0.703-0.706)$ and point to a mantle or deep crustal origin [66-70].

(2) Sometimes, two distinct groups of values are found in the same massif (Morin anorthosite) [68] or a progressive increase of the ${ }^{87} \mathrm{Sr} /{ }^{86} \mathrm{Sr}$ ratio is apparent in a suite of differentiated rocks (Laramie anorthosite) [71].

(3) For the acidic rocks associated with anorthosites, the ${ }^{87} \mathrm{Sr} /{ }^{86} \mathrm{Sr}$ initial ratio cannot give a definite answer on the relationship between the two rock types. Moreover, the situation seems variable from area to area. 
Fig. 11. Chondrite-normalized concentration ranges of the transition elements (Sc to $\mathrm{Cu}$ ) for five jotunitic liquids. The heavy curve indicates the average andesite composition [61].

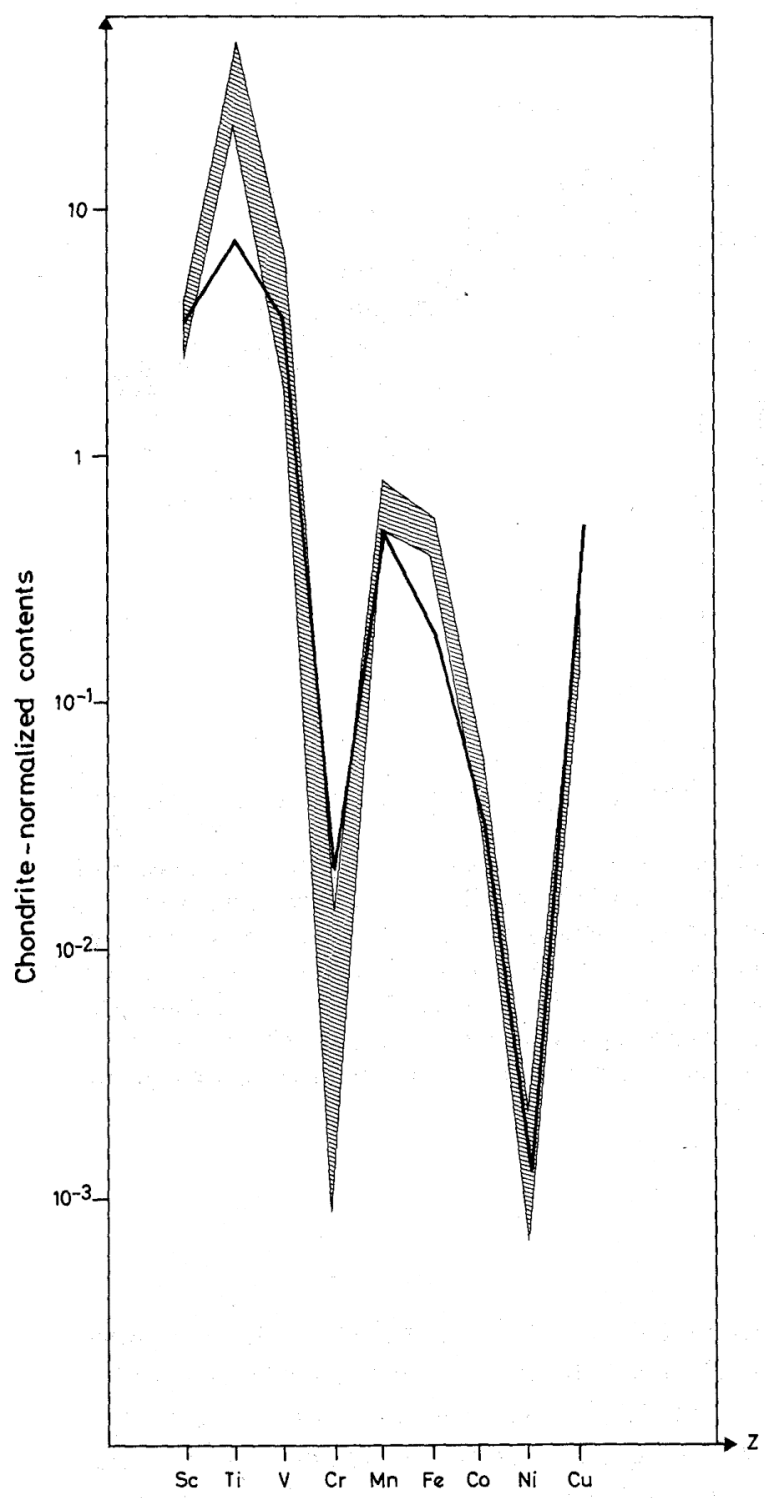

\subsection{Rogaland data}

Strontium isotope measurements have been obtained on a VARIAN TH 5 mass spectrometer. Values are normalized to a ${ }^{86} \mathrm{Sr} /{ }^{88} \mathrm{Sr}$ ratio of 0.1194 . Ten determinations of the Eimer-Amend standard yield an average value of $0.70807 \pm 0.00014(2 \sigma)$.

More than fifty measurements on Rogaland rocks are plotted in Fig. 12 in relation to the order of succession of different intrusions.

The values can be distributed in three groups:

(1) The first group includes the lowest initial ratios of the province $(0.7030-0.7045)$ corresponding to the oldest intrusions, namely the Egersund-Ogna body and the Lakssvelefjeld norite, emplaced during the first tectonic phase, which has deformed the Egersund-Ogna body [24]. 
(2) The second group comprehends all the anorthositic massifs emplaced after the first tectonic phase; the $\left({ }^{87} \mathrm{Sr} /{ }^{86} \mathrm{Sr}\right)_{0}$ ratio shows small variations within this group, from 0.7050 to 0.7065 , except an abnormally high value $(0.7080)$ for a quartz jotunite in the Eia-Rekefjord intrusion. The Lyngdal hornblende-granodiorite has a low initial ratio (0.7054) [73] comparable to that of the anorthosites of this group. The charnockitic dykes and the pegmatites cutting across the Hidra anorthosite have initial ratio of 0.7085 , intermediate between those of group 2 and 3. We will discuss this value later.

(3) The third group includes all the acidic charnockitic rocks (mangerite, quartz mangerite and Farsund charnockite) with high ratios $(>0.710)$.

\subsection{Interpretation and discussion}

\subsubsection{Anorthosites, norites and jotunites (groups 1 and 2)}

For these rocks, the relatively low values of the initial ratios suggest a source region in the upper mantle. A deep crustal origin can equally be surmised because of the low values obtained for pyroxene granulite terranes [7476].

Each massif is isotopically homogeneous except for the Egersund-Ogna body whose central anorthosite has a mean ratio of 0.7035 while the gneissic leuconoritic border shows evident signs of granulation-recrystallization and is characterized by a significantly higher ratio (0.7045). A similar increase of the initial ratio in granulated products has already been observed in the Morin anorthositic body [68]. In the Egersund-Ogna border rocks, the values of the $\mathrm{Rb} / \mathrm{Sr}$ ratio $(<0.05)$ are, however, much too low to explain the observed increase by an isotopic rehomogenization during the granulation, even if we suppose a period as long as $1 \mathrm{~b} . \mathrm{y}$. between initial crystallization and recrystallization. Another possibility must be invoked. The increase in the ${ }^{87} \mathrm{Sr} /{ }^{86} \mathrm{Sr}$ ratio in the border rocks could be due to a uniform contamination of the whole body by a radiogenic Sr-enriched material. The rocks with the lowest $\mathrm{Sr}$ concentration (i.e. the border rocks) will look most severely contaminated isotopically. It should however be noted that the plagioclases of these border rocks are very poor in $\mathrm{K}, \mathrm{Rb}, \mathrm{Ba}$ in contrast to those of the centre, which is not in favour of a contamination process.

On the scale of the province, the intermassif variations of the initial ratios (the increase from 0.7035 to 0.7065 ) can theoretically be explained either by crustal contamination or by melting of a chemically heterogeneous mantle. A process of progressive crustal contamination was first invoked by Michot and Pasteels [69] and by Pasteels et al. [72] who saw on the scale of the province as well as of the Egersund-Ogna and Bjerkrem-Sogndal massifs, a progressive increase with time of the initial ratio. However, here again the geochemical characteristics of some rocks are not easily reconcilable with a process of important crustal contamination, namely the EiaRekefjord jotunites and associated dykes (average value: 0.7065 ) can have very low contents in $\mathrm{Rb}, \mathrm{Th}, \mathrm{U}$.

Moreover, the progressive enrichment is not confirmed by the newly available data for the last intrusions. Values lower than those reported for previous intrusions have indeed been obtained (Hidra: 0.7054; Garsaknatt: 0.7055; Lyngdal hornblende-granodiorite: 0.7054$)$.

The intermassif variations must thus be explained by other models. Magmas could have been generated by a disequilibrium melting process [77] or, more probably, considering the $\mathrm{Sr}$ diffusion velocities at mantle temperature [78], the magmas could result from partial melting of a mineralogically heterogeneous material on a bigger scale [79]. It is thus plausible that the upper mantle underlying the Rogaland complex has been heterogeneous through time and space and has generated by partial melting isotopically different magmas.

\subsubsection{Acidic rocks}

The Lyngdal hornblende-granodiorite has a low initial ratio (0.7054) comparable to those of the anorthosites and it shows a negative Eu anomaly $\left(\mathrm{Eu} / \mathrm{Eu}^{*}=0.80\right)$ : these features suggest a genetic relation between the anorthosites and the granodior-ite, this latter rock corresponding to a late-differentiation liquid. For the other acidic rocks (mangerite and quartz mangerite; Farsund charnockite), the $\mathrm{Rb}$-Sr whole-rock age is lower than the $\mathrm{U}-\mathrm{Pb}$ zircon age $[59,69]$ and corresponds probably to the closure of the Rb-Sr whole-rock system*. If so, the initial ratio deduced from the isochron is higher than the true initial ratio of crystallization time. This ratio can be

\footnotetext{
* For the mangerites and quartz mangerites, the hypothesis of a mixing line should be rejected on the basis of the petrographic similarity of the samples.
} 
calculated for the Bjerkrem-Sogndal lopolith because we can estimate the average $\mathrm{Rb} / \mathrm{Sr}$ ratio of the acidic rocks and the time interval during which the $\mathrm{Rb} / \mathrm{Sr}$ system was open, namely, $70 \mathrm{~m} . \mathrm{y}$. The value obtained $(0.7085)$ is closer but still higher than the values measured for the anorthosites. Thus the hypothesis of a crustal contamination of the Bjerkrem-Sogndal acidic rocks by supracrustal material (surrounding gneisses) must be put forward. The Farsund charnockite keeps a high initial ratio (0.7128) even after correction for the open system $(0.7010)$ and it shows no Eu anomaly. This rock should thus correspond to an anatectic melt without any relation with anorthosites. The dykes cutting through the Hidra anorthosite have geochemical characteristics (large negative Eu anomaly, for example) comparable to those of the quartz mangerites: their initial ratio deduced from an isochron is 0.7085 , higher than the initial ratio of the anorthosite (0.7054). The U-Pb age of these dykes being unknown, it is not possible to correct the initial ratio taking into account a possible late closing of the $\mathrm{Rb}-\mathrm{Sr}$ system.

Fig. 12. Variation of the Sr isotopic composition as a function of time (arbitrary units) in Rogaland.

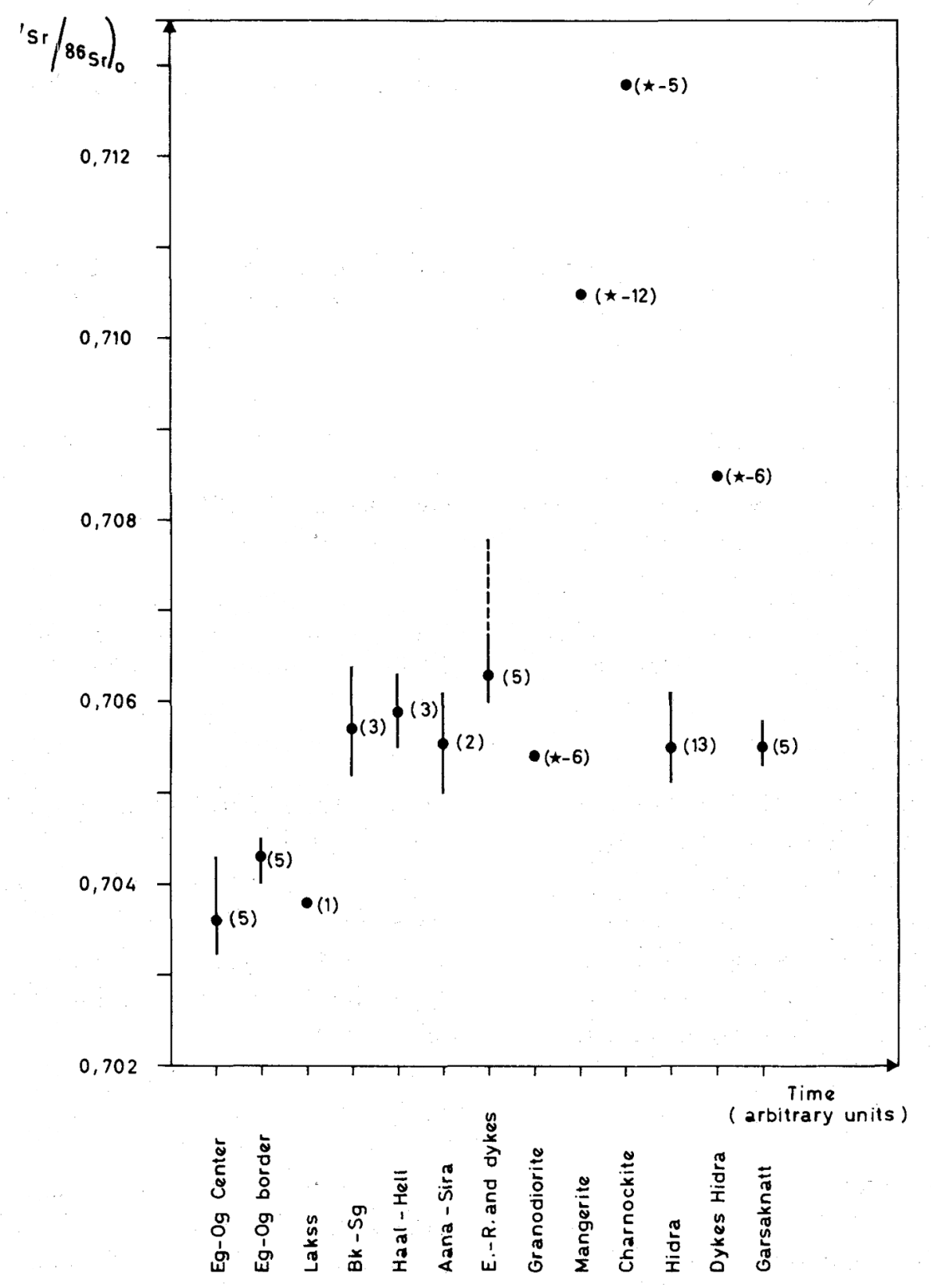

The order of succession of the intrusions is deduced from field relationships and from available geochronological data [59,69,72]. For the $\mathrm{Rb}$-poor rocks (anortho-site, norite and jotunite), the initial ratio is calculated from the measured ratio by taking into account the in situ decay of ${ }^{87} \mathrm{Rb}$ and assuming an age of 1000 m.y. For the acidic rocks, the initial ratio is deduced from Rb-Sr whole-rock isochrons ([73], D.

Demaiffe, unpublished data, 1976). Range of values in each unit indicated by vertical bars; $\bullet=$ average value; (n) = number of values; $(\star-p)$ $=$ initial ratio from isochron of $\mathrm{p}$ points. 


\subsection{Conclusions}

Anorthosites, norites and jotunites have low ${ }^{87} \mathrm{Sr} /{ }^{86} \mathrm{Sr}$ initial ratios suggesting an upper mantle or deep crustal origin. Also the $\mathrm{O}$ isotopic composition (see section 7) seems in favour of a mantle origin.

Although a crustal contamination process cannot be definitely rejected on account of the geological environment, it seems that the observed intermassif variations (from 0.7035 to 0.7065 ) are representative of the source region itself (and not of an hybridization process) and correspond to chemical heterogeneities in the source rather than to disequilibrium melting.

In the acidic rocks, one may distinguish on the basis of the $\mathrm{Sr}$ isotopic composition and of the REE geochemistry, late-stage liquids of anorthositic differentiation, pure anatectic melts and contaminated residual liquids.

\section{Oxygen isotopic composition}

The $\mathrm{O}$ isotopic composition has been determined on whole-rock anorthosites, norites, jotunites and charnockites [80].

For the anorthosites, norites and jotunites, the $\delta^{18} \mathrm{O}$ values are in the range $5.2-6.6 \%$ which is very close to the "magmatic anorthosite range" defined by Taylor [81]. These values are characteristic of unaltered mantle material (basalts, gabbros, andesites, etc.). A mantle origin for the anorthosites is thus compatible with considerations based on both $\mathrm{Sr}$ and $\mathrm{O}$ isotopic compositions.

For the acidic rocks, the range of $\delta^{18}$ O.values (6.0-7.5 \% $)$ is slightly higher than for the anorthosites and again comparable to Taylor's data [81].

They are consistent with the hypothesis of a comagmatic relation between charnockites and anorthosites, although a small-scale contamination by supracrustal rocks of higher $\delta^{18} \mathrm{O}$ cannot entirely be ruled out. The $\mathrm{O}$ isotopes in acidic rocks fail to show the variations observed in the $\mathrm{Sr}$ isotopic compositions. It seems therefore that the $\delta^{18} \mathrm{O}$ values alone cannot give a definite answer as to the origin of the acidic rocks, especially those emplaced or generated in high-grade metamorphic terrains. Indeed there exists a kind of isotopic convergence in the $\mathrm{O}$ isotopic composition between rocks of mantle origin and rocks of deep crustal source $[82,83]$.

\section{General conclusions}

The general conclusions that can be drawn from the trace element geochemistry and from the isotopic composition bear on the parental magma, the differentiation process of the anorthosites and the origin of the acidic rocks.

\subsection{Evidence in favour of parental magmas of different compositions}

Three pieces of evidence point to different compositions:

(1) The trace elements $\mathrm{Sr}, \mathrm{Ba}$ and $\mathrm{Rb}$ and the major elements $\mathrm{Ca}$ and $\mathrm{K}$ show variations of great amplitude in plagioclases and rocks. If it is accepted that the distribution of these elements is mainly controlled by phenomena in which equilibrium between solid and liquid has been reached, it is difficult to explain the range of observed concentrations solely by variation in the distribution coefficients or by fractional crystallization. It is therefore necessary to call upon a variation in the initial content of trace and major elements in the parental liquids. Two types of composition can account for the extension of the variation: the first one, of basic composition (poor in $\mathrm{K}, \mathrm{Rb}, \mathrm{Ba}, \mathrm{Sr}$ and rich in $\mathrm{Ca}$ ) could give rise to labradorite anorthosites; the second one, of intermediate type (richer in $\mathrm{K}, \mathrm{Rb}, \mathrm{Ba}, \mathrm{Sr}$ and poor in $\mathrm{Ca}$ ), could yield andesine anorthosites. The genetic relationship between these two magma types is still to be established. In Rogaland, the occurrence in the same massif (EgersundOgna) of rocks with andesine plagioclase and rocks with labradorite plagioclase cannot be explained by a simple fractional crystallization.

(2) The more basic overall character, compared to other massifs, of Egersund-Ogna (deduced from the nature of the average plagioclase) and of the Lakssvelefjeld intrusion, is to be put together with the fact that the Sr isotopic initial ratios have the lowest values in the province. A relationship between alkalinity of the magma and initial 
ratio, as in the case of volcanic rocks [84], could also exist for the anorthosites. Moreover, if we remember that these geochemical and isotopic features characterize the "basic" bodies which are the oldest and that their solidification is separated from the emplacement of the other massifs by an episode of pervasive regional deformation (first tectonic phase of Michot [24]), it is possible to link the variation in time with a major modification in the tectonic evolution of the area.

(3) The parental magmas in equilibrium with labradorite anorthosites (e.g. Iceland, Fig. 9) show a lower La/Yb ratio than those observed or calculated for the liquids of the andesine-type anorthosites (Bjerkrem-Sogndal, Hidra, Eia-Rekefjord). Such a difference cannot be explained by fractional crystallization at low pressure because, in this process, the hygro-magmatophile character of the REE does not change their distribution, i.e. the $\mathrm{La} / \mathrm{Yb}$ ratio. On the contrary, garnet segregation at depth or partial melting of assemblages of different mineralogical compositions, with or without garnet, could explain the important variations of the La/Yb ratio in the liquids. More data on the REE concentrations in parental liquids of other labradoritic massifs are needed.

\subsection{Evidence in favour of a jotunitic parental magma}

There exists in Rogaland some geochemical evidence in favour of parental liquids of jotunitic composition among the various compositions possible for the parental liquids.

(1) The chilled border facies of the Hidra and Garsaknatt anorthosites show no Eu anomaly and have a jotunitic composition.

(2) The quantitative modelling of the Bjerkrem-Sogndal differentiation process leads to an initial liquid which shows a jotunitic character on the basis of the $\mathrm{K}$ content and REE distribution. Moreover, there is no Eu anomaly in the parental liquid for an $\mathrm{Eu}^{3+}$ proportion relative to total $\mathrm{Eu}$ falling within terrestrial values.

(3) In plagioclase phenocrysts, the high $\mathrm{Fe}$ and $\mathrm{Ti}$ contents are compatible with the high $\mathrm{Ti}\left(\sim 4 \% \mathrm{TiO}_{2}\right)$ and $\mathrm{Fe}$ $\left(14-15 \% \mathrm{FeO}_{\text {tot }}\right)$ concentrations in the jotunites; the small dispersion of their trace and major element compositions in the different andesine-type massifs suggests a common nature for the liquids in equilibrium with them.

\subsection{The anorthosite-norite series and the acidic rocks}

Trace element geochemistry shows that fractional crystallization can explain the succession of rocks from anorthosites to norites. However, this process alone is unable to explain the link between andesine-type and labradorite-type anorthosites.

Direct derivation of acidic rocks by fractional crystallization is also possible. According to the proportions of the different lithological terms, deduced from the Bjerkrem-Sogndal modelling, the acidic rocks constitute about $20 \%$ in volume compared to $55 \%$ for the anorthosites and leuconorites and $25 \%$ for the norites. The hypothesis of an origin by melting of a residue of a previous crustal anatexis [49], put forward to justify the high $\mathrm{K} / \mathrm{Rb}$ ratios, is not necessary. High values can simply be derived from fractional crystallization. In some cases, however, contamination phenomena by assimilation or hybridization of surrounding gneisses may also occur, as shown by the $\mathrm{Sr}$ isotopes, and superimpose their effects on those of fractional crystallization. The volume of the acidic rocks cogenetically associated with the anorthosite is therefore increased. It is not possible to determine the respective importance of these two mechanisms through $\mathrm{K}$ and $\mathrm{Rb}$ geochemistry. The REE and $\mathrm{Sr}$ isotopes will constitute useful tracers when more precise data on the composition of deep gneisses are available.

\subsection{Characteristics of the jotunitic magma}

The major and trace element geochemistry [33] of the jotunitic magma is characterized by high Ti and P abundances, low $\mathrm{Si}$, high $\mathrm{Fe} / \mathrm{Mg}$ and $\mathrm{K}_{2} \mathrm{O} / \mathrm{SiO}_{2}$ ratios. It belongs to the subalkaline series; the transition elements ( $\mathrm{V} / \mathrm{Ni}$ and $\mathrm{Ni} / \mathrm{Co}$ ratios) indicate calc-alkaline affinities. The jotunitic magma shows from massif to massif variable $\mathrm{REE}$ contents and $\mathrm{K} / \mathrm{Rb}$ ratios. The $\mathrm{La} / \mathrm{Yb}$ ratio is but slightly variable. An upper mantle or deep crustal origin is indicated by the low ${ }^{87} \mathrm{Sr} /{ }^{86} \mathrm{Sr}$ initial ratio and is consistent with the ${ }^{18} \mathrm{O} /{ }^{16} \mathrm{O}$ ratios.

Each of these characteristics constitutes important constraints to assess the physico-chemical conditions of magma genesis. The problem of the petrogenesis of jotunitic liquids is, however, difficult to approach owing to the small number of available data. However, it can be stated that andesites are the volcanic liquids whose geochemical characteristics are closest to those of jotunites. The latter can indeed be grossly defined as an 
ilmenite-rich, low-Si andesite. Thus, it is by modifying the models built up for the andesites and adapting them for the proper characteristics of the jotunites that further research must proceed. The role of kaersutite in the distribution of some trace elements has already been envisaged [33] as well as, following Kushiro [85], that of Ti and $\mathrm{P}$ on the pressure conditions of genesis [4]. The problem of anorthosite should thus be but a corollary to a larger one, namely the calc-alkaline magmatism.

\section{Acknowledgements}

The authors have greatly benefited from discussions with J. Michot, S. Deutsch, P. Pasteels, W.G. Griffin, M. Treuil, C.J. Allègre and M. Javoy. They are very grateful to I. Roelandts and J. Hertogen for permission to use some chemical data and R. Zeino-Mahmalat for providing unpublished data;

The Sr isotope analyses were performed in the Belgian Centre for Geochronology. Rubidium and $\mathrm{Sr}$ concentrations in some rocks were determined by M. Delvigne and F. Durez (M.R.A.C, Tervuren) under the supervision of J. Delhal. The O isotopes were analysed by one of us (D.D.) in the Laboratoire de Géochimie des Isotopes stables, Université de Paris 7.

Field trips to Norway were supported by grants from the Belgian F.N.R.S. D. Demaiffe is a former aspirant of the F.N.R.S. (1971-1976).

\section{References}

1 P. Michot, Essai sur la géologie de. la catazone (deuxième note), Acad. R. Belg., Bull. Cl. Sci., Sér. 5, 38 (1952) 495.

2 N. Herz, Anorthosite belts, continental drift, and the anorthosite event, Science 164 (1969) 944.

3 J.D.A. Piper, Paleomagnetic evidence for a Proterozoic super-continent, Phil. Trans. R. Soc. Lond., Ser. A, 280 (1976) 469.

4 D. De Waard, J.C. Duchesne and J. Michot, Anorthosites and their environment, in Géologie des Domaines Cristallins, J. Bellière and J.C. Duchesne, eds. (Centenaire Société Géologique de Belgique, Liège, 1974) 323.

5 D. Bridgwater and B.F. Windley, Anorthosites, post-orogenic granites, acid volcanic rocks and crustal development in the North Atlantic Shield during the Mid-Pro-terozoic, Geol. Soc. S. Afr. Spec. Publ. 3 (1973) 307.

6 P. Michot, La géologie des zones profondes de l'écorce terrestre, Ann. Soc. Géol. Belg., 80 (1956) 19.

7 P. Michot, La structure continentale, Acad. R. Belg., Bull. Cl. Sci., Sér. 5, 49 (1963) 1337.

8 V.V. Beloussov, Modern concepts on the structure and development of the earth's crust and the upper mantle of continents, Q. J. Geol. Soc. Lond. 122 (1966) 293

9 E.V. Pavlovsky, Cratonisation de la croûte continentale (aperçu sous l'angle de la géologie historique), in: Géologif des Domaines Cristallins, J. Bellière and J.C. Duchesne, eds. (Centenaire Société Géologique de Belgique, Liège, 1974) 223.

10 D.L. Anderson, Chemical plumes in the mantle, Geol. Soc. Am. Bull. 86 (1975) 1593.

11 J. Martignole and K. Schrijver, The level of anorthosites and its tectonic pattern, Tectonophysics 10 (1970) 403.

12 J.F. Dewey and K.C.A. Burke, Tibetan, Variscan and Pre-cambrian basement reactivation: products of continental collision, J. Geol. 81 (1973) 683

13 J.A. Wood, J.S. Dickey, Jr., U.B. Marvin and B.N. Powell, Lunar anorthosites and a geophysical model of the moon, Proc. Apollo 11 Lunar Sci., Conf., Geochim. Cosmochim. Acta, Suppl. 1,1 (1970) 965.

14 S.R. Taylor, Lunar Science: A Post-Apollo View (Pergamon, Oxford, 1975) 372 pp.

15 A.F. Buddington, Adirondack igneous rock and their metamorphism, Geol. Soc. Am. Mem. 7 (1939) 1.

16 A.F. Buddington, Differentiation trends and parental magmas for anorthositic and quartz mangerite series, Adirondacks, New York, Geol. Soc. Am. Mem. 132 (1972) 477.

17 N.L. Bowen, The problem of anorthosites, J. Geol. 25 (1917) 209.

18 A.R. Philpotts, Origin of the anorthosite-mangerite rocks in southern Quebec, J. Petrol. 7 (1966) 1. 
Published in: Earth and Planetary Science Letters (1978), vol. 38, pp. 249-272.

Status : Postprint (Author's Version)

19 D. De Waard, The anorthosite-charnockite suite of rocks of Roaring Brook Valley in the eastern Adirondacks (Marcy massif) Am. Mineral. 55 (1970) 2063.

20 R.F. Emslie, The geology of the Michikamau intrusion, Labrador, Geol. Surv. Can. Paper 68-57 (1970) 85 pp.

21 E.H. Kranck, Anorthosites and rapakivi, magmas from the lower crust, in: Origin of Anorthosites and Related Rocks, Y.W. Isachsen, ed., N.Y. State Mus. Sci. Serv., Mem. 18 (1969) 93.

22 P. Henderson, S.J. Fishlock, J.C. Laul, T.D. Cooper, R.L. Conard, W.V. Boynton and R.A. Schmitt, Rare earth element abundances in rocks and minerals from the Fiskenaesset complex, West Greenland, Earth Planet. Sci. Lett. 30 (1976) 37.

23 B.F. Windley, Archaean anorthosites: a review with the Fiskenaesset complex, West Greenland, as a model for interpretation, Geol. Soc. S. Afr. Spec. Publ. 3 (1973) 319.

24 P. Michot, La géologie de la catazone: le problème des anorthosites, la palingenèse basique et la tectonique catazonale dans le Rogaland méridional (Norvège méridionale), Norg. Geol. Unders. 212g (1960) 1.

25 J. Michot and P. Michot, The problem of the anorthosites: the south Rogaland igneous complex (southwestern Norway). In: Origin of Anorthosites and Related Rocks, Y.W. Isachsen, ed., N.Y. State Mus. Sci. Serv., Mem. 18 (1969) 399.

26 D. Demaiffe, J.C. Duchesne, J. Michot and P. Pasteels, Le massif anorthosito-leuconoritique d'Hidra et son facies de bordure, C.R. Acad. Sci. Paris, Sér. D, 277 (1973)17.

27 R.F. Emslie, Pyroxene megacrysts from anorthositic rocks: new clues to the source and evolution of the parent magmas, Can. Mineral. $13(1975) 138$.

28 P. Michot, Le magma plagioclasique, Geol. Rundsch. 54 (1965)956.

29 J.C. Duchesne, Iron-titanium oxide minerals in the Bjerkrem-Sogndal massif, southwestern Norway, J. Petrol. 13 (1972) 57.

30 J.C. Duchesne, Pyroxenes et olivines dans le massif de Bjerkrem-Sogndal (Norvège méridionale); contribution à l'étude de la série anorthosite-mangérite, 24th Int. Geol. Congr., Montreal, Sect. 2 (1972) 320.

31 J. Michot, Le massif complexe anorthosito-leuconoritique de Haaland-Helleren et la palingenèse basique, Acad. R. Belg., Cl. Sci. Mém., Collect. 4, 2e Sér., 15-1 (1961) 95 pp.

32 J. Michot, Anorthosite et recherche pluridisciplinaire, Ann. Soc. Géol. Belg. 95 (1972) 5.

33 J.C. Duchesne, I. Roelandts, D. Demaiffe, J. Hertogen, R. Gijbels and J. De Winter, Rare-earth data on monzonoritic rocks related to anorthosites and their bearing on the nature of the parental magma of the anorthositic suite, Earth Planet. Sci. Lett. 24 (1974) 325.

34 T. Falkum, J.R. Wilson, M.P. Annis, S. Fregerslev and H.D. Zimmermann, The intrusive granites of the Farsund area, South Norway, Norsk Geol. Tidsskr. 52 (1972) 463.

35 J.B. Gill and V.R. Murthy, Distribution of K, Rb, Sr and Ba in Nain anorthosite plagioclase, Geochim. Cosmochim. Acta 34 (1970) 401.

36 V.R. Murthy and W.L. Griffin, K/Rb fractionation by plagioclase feldspars, Chem. Geol. 6 (1970) 265.

37 W.L. Griffin, B. Sundvoll and H. Kristmannsdottir, Trace element composition of anorthosite plagioclase, Earth Planet. Sci. Lett. 24 (1974) 213.

38 J.C. Duchesne, Les relations Sr-Ca et Ba-K dans les plagioclases des anorthosites du Rogaland méridional, Ann. Soc. Géol. Belg. 90 (1968) 643.

39 J.C. Duchesne, Le rapport $\mathrm{Sr} / \mathrm{Ca}$ dans les plagioclases du massif de Bjerkrem-Sogndal (Norvège méridionale) et son évolution dans la cristallisation fractionnée du magma plagioclasique, Chem. Geol. 8 (1971) 123.

40 R. Zeino-Mahmalat, Untersuchungen an Plagioklasen aus dem Anorthosit-Komplex von Åna-Sira (Südnorwegen), Doctorate Thesis, Technische Universitàt Clausthal, Clausthal (1972) unpublished.

41 J.C. Duchesne, Sur la provenance de xénolithes anorthositiques dans le massif de Bjerkrem-Sogndal (Norvège), Ann. Soc. Géol. Belg. 93 (1970) 523

42 J.A. Philpotts and C.C. Schnetzler, Phenocryst-matrix partition coefficients for $\mathrm{K}, \mathrm{Rb}, \mathrm{Sr}$ and Ba, with applications to anorthosite and basalt genesis, Geochim. Cosmo-chim. Acta 34 (1970) 307.

43 C. Dupuy and C.J. Allègre, Fractionnement K/Rb dans les suites ignimbritiques de Toscane; un exemple de rejuvénation crustale, Geochim. Cosmochim. Acta 36 (1972) 437. 
44 A. Vitrac-Michard and C.J. Allègre, A study of the formation and history of a piece of continental crust by ${ }^{87} \mathrm{Rb}-{ }^{87} \mathrm{Sr}$ method: the case of the French oriental Pyrénées, Contrib. Mineral. Petrol. 50 (1975) 257.

45 M. Treuil and J.L. Joron, Utilisation des éléments hygro-magmatophiles pour la simplification de la modélisation quantitative des processus magmatiques; exemples de l'Afar et de la dorsale médioatlantique, Soc. It. Mineral. Petrol. 31 (1975) 125.

46 L.R. Wager and G.M. Brown, Layered Igneous Rocks (Oliver and Boyd, London, 1968) 588 pp.

47 I. Roelandts, Contribution au dosage par activation neutronique des terres rares et d'autres éléments en trace dans les roches magmatiques, Doctorat Thesis, Univ. of Liège, Liège (1975) unpublished.

48 D..M. Shaw, A review of K/Rb fractionation trends by covariance analysis, Geochim. Cosmochim. Acta 32 (1968) 573.

49 T.H. Green, A.O. Brunfelt and K.S. Heier, Rare earth element distribution and K/Rb ratios in granulites, mangerites and anorthosites, Lofoten-Vesteraalen, Norway, Geochim. Cosmochim. Acta 36 (1972) 241.

50 R.C. Reynolds, P.R. Whitney and Y.W. Isachsen, K/Rb ratios in anorthositic and associated charnockitic rocks of the Adirondacks, and their petrogenetic implications. In: Origin of Anorthosite and Related Rocks, Y.W. Isachsen, ed., N.Y. State Mus. Sci. Serv., Mem. 18 (1969) 411 .

51 J.A. Philpotts, C.C. Schnetzler and H.H. Thomas, Rare earth abundances in an anorthosite and a mangerite, Nature 212 (1966) 805.

52 I. Roelandts and J.C. Duchesne, Rare earth elements in apatite from layered norites and iron-titanium ore-bodies related to anorthosites (Rogaland, S.W. Norway), Proc. 2nd Symp. on the Origin and Distribution of the Elements (1977) in press

53 T.P. Paster, D.S, Schauwecker and L.A. Haskin, The behaviour of some trace elements during solidification of the Skaergaard layered series, Geochim. Cosmochim. Acta 38 (1974) 1549.

54 J.A. Philpotts, Redox estimation from calculation of $\mathrm{Eu}^{2+}$ and $\mathrm{Eu}^{3+}$ concentrations in natural phases, Earth Planet. Sci. Lett. 9 (1970) 257.

55 B.B. Jensen, Patterns of trace element partitioning, Geochim. Cosmochim. Acta 37 (1973) 2227

56 T.R. Wildeman and L.A. Haskin, Rare earths in Precambrian sediments, Geochim. Cosmochim. Acta 37 (1973) 419.

57 T. Koljonen and R.J. Rosenberg, Rare earth elements in granitic rocks, Lithos 7 (1974) 249.

58 D. Demaiffe, J.C. Duchesne and J. Hertogen, Trace element variations and isotopic composition of charnockitic acidic rocks related to anorthosites (Rogaland, S.W. Norway), Proc. 2nd Symp. on the Origin and Distribution of the Elements (1977) in press.

59 D. Demaiffe, J. Michot and P. Pasteels, Time relationship and strontium isotopic evolution in the magma of the anorthosite-charnockite suite of South Norway, Int. Meet, on Geochronology, Cosmochronology and Isotope Geology, Paris (1974) abstract.

60 C.J. Allègre, M. Javoy and G. Michard, Etude de la distribution et de l'abondance des éléments de transition dans l'écorce terrestre comparée à celles des terres rares, in: Origin and Distribution of the Elements, L.H. Ahrens, éd. (Pergamon, Oxford, 1968) 913.

61 S.R. Taylor, Trace element chemistry of andesites and associated calc-alkaline rocks, in: Proceedings of the Andesite Conference, A.R. McBirney, éd., Oreg. Dep. Geol. Miner. Ind., Bull. 65 (1969) 43.

62 S.R. Taylor, M. Kaye, A.J.R. White, A.R. Duncan and A. Ewart, Genetic significance of Co, Cr, Ni, Sc and V content of andesites. Geochim. Cosmochim. Acta 33 (1969) 275.

63 G.W. De Vore, The role of absorption in the fractionation and distribution of elements, J. Geol. 63 (1955) 159.

64 J. Martignole, La formation des dépôts d'ilménite-magnétite durant la mise en place des anorthosites, in: Les Roches Plutoniques dans leurs Rapports avec les Gîtes Minéraux, E. Raguin, coll. (Masson, Paris, 1973) 233.

65 J.C. Duchesne, Les gisements d'oxydes de fer et titane dans les roches anorthositiques du Rogaland (Norvège méridionale), in: Les Roches Plutoniques dans leurs Rapports avec les Gîtes Minéraux, E. Raguin, coll. (Masson, Paris, 1973) 241.

66 S.A. Heath and H.W. Fairbairn, ${ }^{87} \mathrm{Sr} /{ }^{86} \mathrm{Sr}$ ratios in anorthosites and some associated rocks, in: Origin of Anorthosites and Related Rocks, Y.W. Isachsen, ed., N.Y. State Mus. Sci. Serv., Mem. 18 (1969) 99.

67 J.M. Barton and R. Doig, Rb-Sr isotopic studies of the Lac Croche Complex, Grenville Province, Quebec, Can. J. Earth Sci. 9(1972) 1180.

68 J.M. Barton and R. Doig, Sr isotopic studies of the origin of the Morin anorthosite complex, Quebec, Contrib. Mineral. Petrol. 61 (1977) 219. 
69 J. Michot and P. Pasteels, La variation du rapport $\left({ }^{87} \mathrm{Sr} /{ }^{86} \mathrm{Sr}\right)_{0}$ dans les roches génétiquement associées au magma plagioclasique, Ann. Soc. Géol. Belg. 92 (1969) 255.

70 S. Deutsch and J. Michot, Variations of the $\left({ }^{87} \mathrm{Sr} /{ }^{86} \mathrm{Sr}\right)_{0}$ ratio in anorthositic intrusions, 3rd European Colloq. of Geochronology, Oxford (1973) abstract.

71 G.V. Subbarayudu, F.A. Hills and R.E. Zartman, Age and Sr isotopic evidence for the origin of the Laramie anorthosite-syenite complex, Laramie Range, Wyoming, Annu. Meet. Geol. Soc. Am., Salt Lake City, Utah, 7, 7 (1975) abstract.

72 P. Pasteels, J. Michot and J. Lavreau, Le complexe éruptif du Rogaland méridional (Norvège) : signification pétrogénétique de la farsundite et de la mangérite quartzi-que des unités orientales; arguments géochronologiques et isotopiques, Ann. Soc. Géol. Belg. 93 (1970) 453 .

73 S. Pedersen and T. Falkum, Rb-Sr isochrons for the granitic plutons around Farsund, southern Norway, Chem. Geol. 15 (1975) 97.

$74 \mathrm{CM}$. Spooner and H.W. Fairbairn, ${ }^{87} \mathrm{Sr} /{ }^{86} \mathrm{Sr}$ initial ratios in pyroxene granulite terranes, J. Geophys. Res. 75 (1970) 6706.

75 C.R. Evans, Geochronology of the Lewisian basement near Lochinver, Sutherland, Nature 207 (1965) 54.

76 J.G. Holland and R. St. J. Lambert, The chemistry and origin of the Lewisian gneisses of the Scottish mainland: the Scourie and Inver Assemblages and subcrustal accretion, Precambrian Res. 2 (1975) 161.

77 R.K. O'Nions and R.J. Pankhurst, Petrogenetic significance of isotope and trace element variations in volcanic rocks from the MidAtlantic, J. Petrol. 15 (1974) 603.

78 A. Hofmann, Diffusion of Ca and Sr in a basalt melt, Carnegie Inst. Washington Yearb. 74 (1975) 183.

79 A. Hofmann and S.R. Hart, An assessment of local and regional isotopic equilibrium in a partially molten mantle, Carnegie Inst. Washington Yearb. 74 (1975) 195.

80 D. Demaiffe and M. Javoy, Oxygen isotope geochemistry of anorthosites and related rocks of South Norway, 4th European Colloq. of Geochronology, Amsterdam (1976) abstract.

81 H.P. Taylor, Oxygen isotope studies of anorthosites with particular reference to the origin of bodies in the Adirondacks Mountains, New York, in: Origin of Anorthosites and Related Rocks, Y.W. Isachsen, ed., N.Y. State Mus. Sci. Serv., Mem. 18 (1969) 111.

82 S. Fourcade and M. Javoy, Rapports ${ }^{18} \mathrm{O} /{ }^{16} \mathrm{O}$ dans les roches du vieux socle catazonal d'In Ouzzal (Sahara algérien), Contrib. Mineral. Petrol. 42 (1973) 235.

83 Y.N. Shieh and H.P. Schwarcz, Oxygen isotope studies of granite and migmatite, Grenville province of Ontario, Canada, Geochim. Cosmochim. Acta 38 (1974) 21.

84 Z.E. Peterman and C.E. Hedge, Related strontium isotopic and chemical variations in oceanic basalts, Geol. Soc. Am. Bull. 82 (1971) 493.

85 I. Kushiro, Pressure effect on the changes of the forsterite-enstatite liquidus boundary with the addition of other cations and the genesis of magma. Carnegie Inst. Washington Yearb. 73 (1974) 248. 